\title{
A Review of Biomonitoring of Phthalate Exposures
}

\author{
Yu Wang ${ }^{1}{ }^{1}$, Hongkai Zhu ${ }^{1}$ and Kurunthachalam Kannan ${ }^{1,2, *}$ \\ 1 Wadsworth Center, New York State Department of Health, Albany, New York, NY 12201, USA; \\ wangyu@mail.nankai.edu.cn (Y.W.); Hongkai.Zhu@health.ny.gov (H.Z.) \\ 2 Department of Environmental Health Sciences, School of Public Health, State University of New York at \\ Albany, Albany, NY 12201, USA \\ * Correspondence: kurunthachalam.kannan@health.ny.gov; Tel.: +1-518-474-0015; Fax: +1-518-473-2895
}

Received: 31 January 2019; Accepted: 29 March 2019; Published: 5 April 2019

Abstract: Phthalates (diesters of phthalic acid) are widely used as plasticizers and additives in many consumer products. Laboratory animal studies have reported the endocrine-disrupting and reproductive effects of phthalates, and human exposure to this class of chemicals is a concern. Several phthalates have been recognized as substances of high concern. Human exposure to phthalates occurs mainly via dietary sources, dermal absorption, and air inhalation. Phthalates are excreted as conjugated monoesters in urine, and some phthalates, such as di-2-ethylhexyl phthalate (DEHP), undergo secondary metabolism, including oxidative transformation, prior to urinary excretion. The occurrence of phthalates and their metabolites in urine, serum, breast milk, and semen has been widely reported. Urine has been the preferred matrix in human biomonitoring studies, and concentrations on the order of several tens to hundreds of nanograms per milliliter have been reported for several phthalate metabolites. Metabolites of diethyl phthalate (DEP), dibutyl- (DBP) and diisobutyl- (DiBP) phthalates, and DEHP were the most abundant compounds measured in urine. Temporal trends in phthalate exposures varied among countries. In the United States (US), DEHP exposure has declined since 2005, whereas DiNP exposure has increased. In China, DEHP exposure has increased since 2000. For many phthalates, exposures in children are higher than those in adults. Human epidemiological studies have shown a significant association between phthalate exposures and adverse reproductive outcomes in women and men, type II diabetes and insulin resistance, overweight/obesity, allergy, and asthma. This review compiles biomonitoring studies of phthalates and exposure doses to assess health risks from phthalate exposures in populations across the globe.

Keywords: phthalate; DEHP; biomonitoring; human exposure; toxicity; reproductive

\section{Introduction}

Phthalates are diesters of phthalic acid (1,2-benzenedicarboxylic acid) and are synthetic organic chemicals used in industries as solvents, plasticizers, and additives in polyvinyl chloride (PVC) plastics or personal care products (PCPs) [1]. More than 25 phthalates are used in commercial applications, with each adding unique qualities to the product into which it is incorporated. Ten commonly used phthalates (Figure 1, Table 1) are dimethyl phthalate (DMP), diethyl phthalate (DEP), dibutyl phthalate (DBP), diisobutyl phthalate (DiBP), benzylbutyl phthalate (BzBP), dicyclohexyl phthalate (DCHP), di(2-ethylhexyl) phthalate (DEHP), di-n-octyl phthalate (DnOP), di-isononyl phthalate (DiNP), and di-isodecyl phthalate (DiDP). DEHP, one of the major phthalates in commerce, was first synthesized for use as a plasticizer in 1933 [2]. The application of DEHP as an additive in polyvinyl chloride (PVC) to impart the flexibility of plastic has made phthalates popular around the world. The addition of phthalates to PVC makes it not only flexible but also malleable and durable. PVC products may contain up to $50 \%$ (by weight) phthalates [1]. 


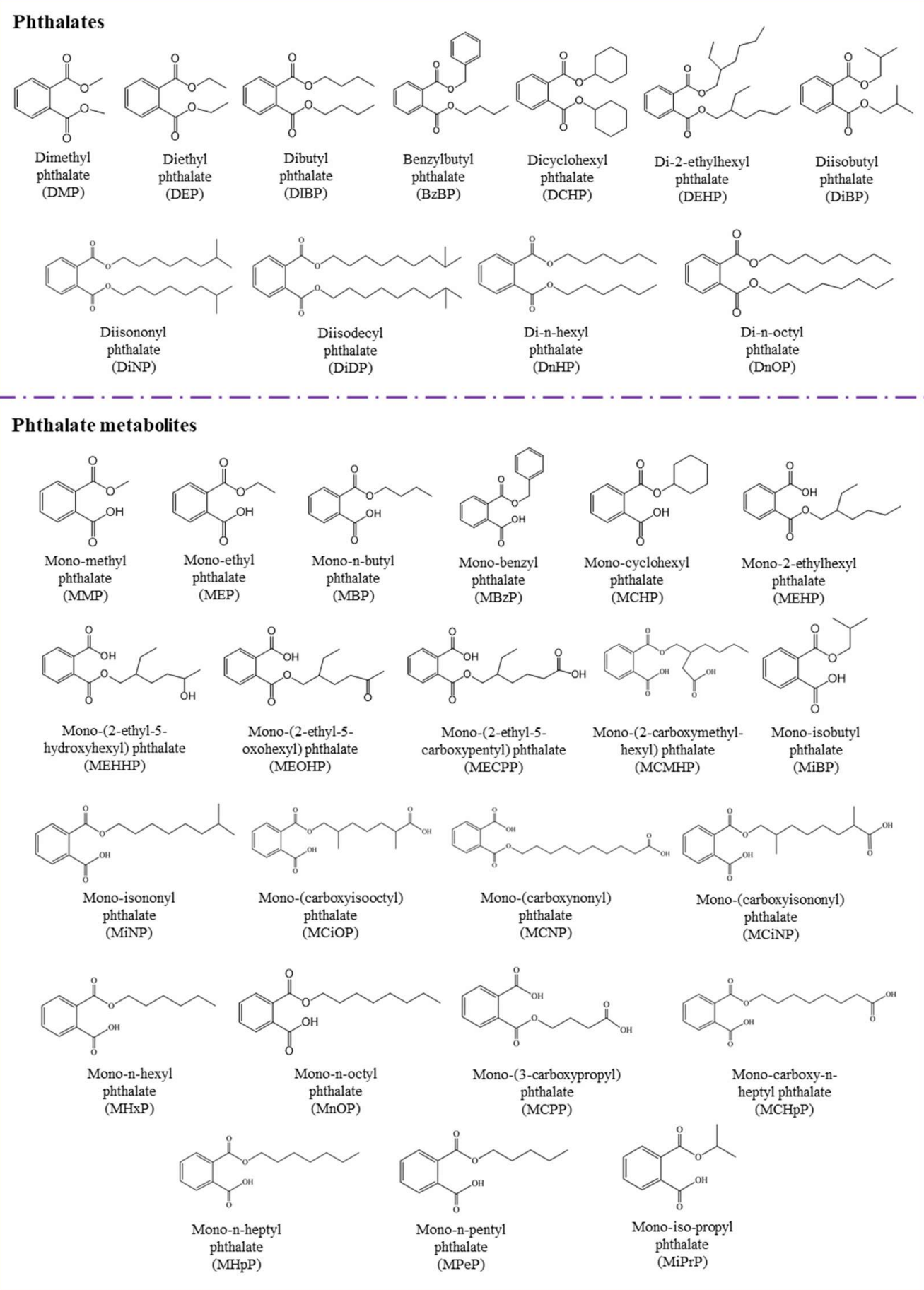

Figure 1. Chemical structures of major phthalates and their metabolites studied in the literature. 
Table 1. Major phthalate diesters and their corresponding metabolites studied in the literature.

\begin{tabular}{|c|c|c|c|}
\hline Parent Compounds & Abb. & Major Metabolites & Abb. \\
\hline Dimethyl phthalate & DMP & Mono-methyl phthalate & MMP \\
\hline Diethyl phthalate & DEP & Mono-ethyl phthalate & MEP \\
\hline Dibutyl phthalate & DBP & Mono-n-butyl phthalate & MBP \\
\hline Benzylbutyl phthalate & $\mathrm{BzBP}$ & $\begin{array}{c}\text { Mono-benzyl phthalate } \\
\text { (some mono-n-butyl phthalate) }\end{array}$ & MBzP \\
\hline Dicyclohexyl phthalate & DCHP & Mono-cyclohexyl phthalate & $\mathrm{MCHP}$ \\
\hline \multirow{5}{*}{ Di-2-ethylhexyl phthalate } & \multirow{5}{*}{ DEHP } & Mono-2-ethylhexyl phthalate & MEHP \\
\hline & & Mono-(2-ethyl-5-hydroxyhexyl) phthalate & $\begin{array}{c}\text { MEHHP } \\
\text { (5OH-MEHP) }\end{array}$ \\
\hline & & Mono-(2-ethyl-5-oxohexyl) phthalate & $\begin{array}{c}\text { MEOHP } \\
\text { (5oxo-MEHP) }\end{array}$ \\
\hline & & Mono-(2-ethyl-5-carboxypentyl) phthalate & $\begin{array}{c}\text { MECPP } \\
(5 c x-M E P P)\end{array}$ \\
\hline & & Mono-(2-carboxymethyl-hexyl) phthalate & $\begin{array}{c}\text { MCMHP } \\
(2 \mathrm{cx}-\mathrm{MMHP})\end{array}$ \\
\hline Diisobutyl phthalate & DiBP & Mono-isobutyl phthalate & MiBP \\
\hline \multirow{2}{*}{ Diisononyl phthalate } & \multirow{2}{*}{ DiNP } & Mono-isononyl phthalate & MiNP \\
\hline & & Mono-(carboxyisooctyl) phthalate & $\mathrm{MCiOP}$ \\
\hline \multirow{2}{*}{ Diisodecyl phthalate } & \multirow{2}{*}{ DiDP } & Mono-(carboxynonyl) phthalate & MCNP \\
\hline & & Mono-(carboxyisononyl) phthalate & MCiNP \\
\hline Di-n-hexyl phthalate & DnHP & Mono-n-hexyl phthalate & $\mathrm{MHxP}$ \\
\hline \multirow{6}{*}{ Di-n-octyl phthalate } & \multirow{2}{*}{ DnOP } & Mono-n-octyl phthalate & $\mathrm{MnOP}$ \\
\hline & & Mono-(3-carboxypropyl) phthalate & MCPP \\
\hline & & Mono-carboxy-n-heptyl phthalate & $\mathrm{MCHpP}$ \\
\hline & & Mono-n-heptyl phthalate & MHpP \\
\hline & & Mono-n-pentyl phthalate & MPeP \\
\hline & & Mono-iso-propyl phthalate & $\mathrm{MiPrP}$ \\
\hline
\end{tabular}

Currently, phthalates are used in many types of products, including building materials, automotive parts, medical devices, food packaging, cosmetics, perfumes, toys, teethers, adhesives, paints, floorings, lubricants, hair sprays, shampoos, soaps, nail polishes, and detergents [3-5]. The annual global production of phthalate was 4.7 million metric tons in 2006 [6,7] and $\sim 8$ million metric tons in 2015 [8]. In most commercial products, DEHP, DiNP, and BzBP are used as additives, and they easily migrate from those products into the environment through evaporation, leaching, and abrasion [9]. Phthalates have been measured in a range of environmental matrices, including sludge, dust, soil, air, and water [4], and are ubiquitous contaminants in the environment.

Phthalates are reproductive and developmental toxicants [10]. In laboratory animal studies, DEHP has been reported to affect the reproductive system and development [11,12]. Further, changes in hepatic structure and function and kidney function as well as disruption of thyroid signaling, immune function, and metabolic homeostasis were reported [13-16]. The US Environmental Protection Agency (EPA) classified DEHP and BzBP as probable and possible human carcinogens, respectively. European authorities have classified phthalates with three to six carbons in their backbone as Repr 1B Agents (i.e., presumed human reproductive toxicants) (https:/echa.europa.eu/substance-information/-/ substanceinfo/100.239.213). 
Human exposure to phthalates arises mainly from ingestion, inhalation, and dermal absorption [17,18]. Human biomonitoring studies have measured parent phthalate in serum [19] and their metabolites in human urine [20,21], semen [22,23], and breast milk [24,25]. Studies have demonstrated that phthalate exposure is associated with oxidative stress in humans [26,27]. Some studies have linked phthalate exposure to premature thelarche [28,29], endometriosis [30,31], low semen quality [32], reduced testosterone levels [33], obesity, diabetes, and breast cancer [34,35]. Phthalates are regarded as endocrine-disrupting compounds [36]. One of the most significant effects of phthalates is in terms of fetal development and reproductive anomalies and is referred to as "phthalate syndrome" (e.g., developmental or testicular effects, insulin like factor 3 production) [37,38]. In addition, phthalate exposure might be linked to insulin resistance and obesity in human populations [39,40].

In 1999, the European Union (EU) temporarily banned the use of six phthalates in children's toys: DiNP, DEHP, DBP, BzBP, DiDP, and DnOP (http://europa.eu/rapid/press-release_IP-05-838_en. $\mathrm{htm}$ ). Further, in 2009, these phthalates were restricted in toys in Europe (https://eur-lex.europa.eu/ legal-content/EN/TXT/?uri=CELEX\%3A32009L0048). The US followed suit in 2008 by passing the Consumer Products Safety Improvement Act, which banned the same six phthalates in children's toys (https://www.cpsc.gov/Regulations-Laws--Standards/Statutes/The-Consumer-Product-SafetyImprovement-Act). Many industries began substituting alternative chemicals for phthalates in their products, and several substitutive phthalate and non-phthalate plasticizers are currently used in many products [41,42]. Although six phthalates are now restricted in children's products in the US and EU, they are unregulated and continue to be used in toys in many other parts of the world, including China and India. In addition, children continue to be exposed to phthalates in cosmetics and PCPs as well as in school supplies made of PVC, including notebooks and binders, art supplies, backpacks, lunchboxes, paperclips, and umbrellas (https://www.sustainableproduction.org/downloads/PhthalateAlternativesJanuary2011.pdf). Raincoats, boots, handbags, and soft plastic shoes also may contain phthalates.

A search on the basis of Web of Science Core Collection, BIOSIS Previews, Derwent Innovations Index, MEDLINE, and ScieELO Citation Index was carried out to identify studies relevant to biomonitoring and epidemiology on phthalates and phthalate metabolites. Topics of interest included studies on phthalates in urine, serum, and other biofluids. The search terms used were: phthalic acid/phthalates OR phthalate metabolites AND biomonitoring OR epidemiological studies. Publications between 2000 and 2018 were extracted. This review provides a summary of human biomonitoring studies of phthalate diesters and their monoester (primary) and oxidative (secondary) metabolites as well as select epidemiological studies that link phthalate exposure to health outcomes in human populations.

\section{Sources of Phthalates}

Owing to their widespread use in consumer products, phthalates are ubiquitous in the environment, and a variety of sources have been reported to contribute to human exposure. For the purpose of exposure analysis, phthalates have often been grouped as lower molecular weight (ester side-chain lengths, one to four carbons; DMP, DEP, and DBP), and higher molecular weight (ester side-chain lengths, five or more carbons; DEHP, DiNP, DiDP, and BzBP) phthalates [43]. The high molecular weight phthalates are used primarily in PVC polymers and plastisol applications, plastics, food packaging, and food processing materials, vinyl toys and vinyl floor coverings, and building products. The low molecular weight phthalates are often used in non-PVC applications, such as personal care products, paints, adhesives, and enteric-coated tablets [44]. BzBP, DEHP, DiNP, DBP, and DiBP are used in toys, bags, gloves, and plastic tubing for improving flexibility and making the polymeric products soft and malleable [4]. DMP and DEP are widely used in cosmetics, such as perfumes, aftershaves, shampoos, makeup, and nail care products [4]. Cosmetics and personal care products are the major sources of human exposure to low molecular weight phthalates. Food packaging plastic film contains phthalates (such as DBP and DEP) at levels of up to $10 \%$ by weight. Plasticizer migration occurs when food packaging films come in direct contact with foods, and fatty foods and high temperatures increase 
the migration [45]. Diet has been a major source of exposure to high molecular weight phthalates, especially DEHP. In particular, foods packaged in plastic/PVC materials contribute to exposure to DEHP in humans [46].

The major source of exposure to DEP — one of the major phthalates found in human urine-is cosmetics and personal care products [17]. Studies have reported elevated concentrations of phthalates in indoor air and dust [47]. In fact, among various contaminants measured in indoor dust, phthalates, especially DEHP and DEP, are the major contaminants in indoor dust and air [46]. Phthalates also were reported to occur in pharmaceuticals, especially in over-the-counter medications/syrups and in pills with enteric coatings [48,49]. Medical devices that are suspected to contain DEHP include intravenous (IV) storage bags, ventilator tubing, IV infusion sets, endotracheal tubes, IV infusion catheters, nasogastric tubes, blood storage bags, enteral and parenteral nutrition storage bags, blood administration sets, urinary catheters, PVC exam gloves, suction catheters, chest tubes, nasal cannula tubing, hemodialysis tubing, syringes, extracorporeal membrane oxygenation tubing, and cardiopulmonary bypass tubing [50].

Exposure doses to phthalates have been calculated through the ingestion of foods, air inhalation, and dust ingestion for the general population in the US (sampled during 2011-2014) (Table 2) [46]. Dust ingestion is a major source of exposure to phthalates in infants and toddlers, whereas diet is the major source for children and adults. The exposure doses are in the range of a sub to low $\mu \mathrm{g} / \mathrm{kg} \mathrm{bw} / \mathrm{d}$. Further details of exposure doses calculated through biomonitoring data are provided below.

Table 2. Human exposure doses to total phthalates for the US population through various pathways $(\mu \mathrm{g} / \mathrm{kg}$ bw/d).

\begin{tabular}{|c|c|c|c|c|c|}
\hline Exposure Route & $\begin{array}{c}\text { Dust } \\
\text { Ingestion }\end{array}$ & $\begin{array}{l}\text { Dust Dermal } \\
\text { Absorption }\end{array}$ & $\begin{array}{c}\text { Personal Care } \\
\text { Products (Dermal) }\end{array}$ & Diet & $\begin{array}{l}\text { Indoor Air } \\
\text { Inhalation }\end{array}$ \\
\hline Infants $\left(<1 \mathrm{y}^{*}\right)$ & 1.12 & 0.001 & 0.0095 & - & 0.845 \\
\hline Toddlers (1-3 y) & 1.7 & 0.0008 & 0.0059 & - & 0.423 \\
\hline Children (3-11 y) & 0.468 & 0.0006 & - & 4.68 & 0.203 \\
\hline Teenagers (11-18 y) & 0.291 & 0.0005 & - & - & 0.089 \\
\hline Adults (>18 y) & 0.233 & 0.0002 & $0.013-0.49$ & 1.03 & 0.07 \\
\hline
\end{tabular}

\section{Biomonitoring of Phthalates}

Due to the ubiquitous occurrence and widespread exposure of phthalates, their metabolites are one of the most examined environmental chemicals in human biomonitoring studies. The reported half-life of phthalates diesters in blood plasma or urine of humans and rodents was less than $24 \mathrm{~h}$. Several studies have reviewed pharmacokinetics of phthalate esters, and these studies have found rapid hydrolysis of diesters to monoesters in the gastrointestinal tract [1,2]. Binding of DEHP metabolites to blood plasma proteins, existence of biliary excretion, and enterohepatic circulation in humans have been suggested [2]. Nevertheless, urinary excretion has been the major elimination pathway of phthalates [2]. Urinary concentrations of phthalate metabolites are generally 5-20 times higher than that in lipid-rich compartments. For example, urinary concentrations of mono-2-ethylhexyl phthalate (MEHP), mono-isobutyl phthalate (MIBP), mono-ethyl phthalate (MEP), and mono-n-butyl phthalate (MBP) were 20-100 times those in blood or milk [24]. Phthalate metabolites have been measured in various body fluids, including urine $[47,51]$, serum $[52,53]$, semen $[32,54]$, breast milk $[55,56]$, and saliva [57] (Table 3). Phthalates can cross the placental barrier [58] and have been measured in amniotic fluid in human studies [59]. To date, studies that report partitioning of phthalates among various tissues and organs in an organism, at state-state exposure conditions, are not available. It is worth noting that a few earlier reviews have described biomonitoring of phthalates in humans [60]. Biomonitoring studies that report concentrations of phthalates metabolites are presented in Table 3. 
Table 3. Reported concentrations of major phthalate metabolites in human specimens collected from various countries.

\begin{tabular}{|c|c|c|c|c|c|c|c|c|c|}
\hline \multirow{2}{*}{ Matrix } & \multirow{2}{*}{ Country/Region } & \multirow{2}{*}{ Studied Population } & \multicolumn{5}{|c|}{ Concentration } & \multirow[b]{2}{*}{ Unit } & \multirow{2}{*}{ Reference } \\
\hline & & & MMP & MEP & MBP & MiBP & MDEHP & & \\
\hline Urine & Australia & 30 non-occupational exposure & & 18.5 & 11.8 & 7.3 & 25.2 & $\mu \mathrm{g} / \mathrm{L} ;$ median & [61] \\
\hline Urine & Austria & 251 children/adolescents; 272 adults; 72 senior citizens & & 25 & 10 & 28 & 15.5 & $\mu \mathrm{g} / \mathrm{L} ;$ median & [62] \\
\hline Urine & Belgium & 261 persons & & 34.3 & 33.3 & 24.3 & 11.7 & $\mu \mathrm{g} / \mathrm{L} ;$ median & [63] \\
\hline Urine & Belgium & 210 adolescents & & & 38.5 & & 52.7 & $\mu \mathrm{g} / \mathrm{L} ;$ median & [64] \\
\hline Urine & Belgium & 123 men 138 women & & 37.6 & 31.3 & 26.2 & 17.1 & $\mu \mathrm{g} / \mathrm{L} ;$ median & [65] \\
\hline Urine & Belgium & 25 persons & & 20.4 & 15.6 & 15.9 & 12.01 & $\mu \mathrm{g} / \mathrm{L} ;$ median & [66] \\
\hline Urine & Brazil & 300 children (6-14 years old). & 8.3 & 57.3 & 42.4 & 43.8 & 109 & $\mu \mathrm{g} / \mathrm{L} ;$ median & [67] \\
\hline Urine & Canada & 3236 persons ( $6-49$ years old) & & 49.1 & 23.8 & & 40.9 & $\mu \mathrm{g} / \mathrm{L} ;$ median & [68] \\
\hline Urine & Canada & 2000 women (first trimester) & & 32.02 & 11.59 & & & $\mu \mathrm{g} / \mathrm{L} ; \mathrm{GM}$ & [69] \\
\hline Urine & Canada & 80 infants & & & & 7.01 & 10.63 & $\mu \mathrm{g} / \mathrm{L} ;$ median & [70] \\
\hline Urine & China & 108 young adults & 31.8 & 37.5 & 67 & 57.2 & 65.3 & $\mu \mathrm{g} / \mathrm{L} ;$ median & [71] \\
\hline Urine & China & 21 women 19 men & 16.5 & 20.7 & 49.6 & 44 & 44.2 & $\mu \mathrm{g} / \mathrm{L} ;$ median & [72] \\
\hline Urine & China & 430 children ( 208 girls and 222 boys) & 15.7 & 4.14 & 21.9 & & 14.3 & $\mu \mathrm{g} / \mathrm{L} ;$ median & [73] \\
\hline Urine & China & 183 samples & 14.6 & 22.1 & 63.5 & 57.1 & 76.1 & $\mu \mathrm{g} / \mathrm{L} ;$ median & [51] \\
\hline Urine & China & 364 males (19-44 years old) & & 28.2 & 47.1 & & 42 & $\mu \mathrm{g} / \mathrm{L} ;$ median & [74] \\
\hline Urine & China & 39 children (5-9 years) & & 28.5 & 232 & 81.3 & 79.1 & $\mu \mathrm{g} / \mathrm{L} ;$ median & [75] \\
\hline Urine & Czech & 117 women & ND & 56.7 & & & 32.2 & $\mu \mathrm{g} / \mathrm{L} ;$ median & [76] \\
\hline Urine & Czech & 120 children & ND & 31.6 & & & 61.9 & $\mu \mathrm{g} / \mathrm{L}$; median & [76] \\
\hline Urine & Denmark & 60 men & & 54.5 & 36.8 & 47.3 & 68.1 & $\mu \mathrm{g} / \mathrm{L}$; median & [77] \\
\hline Urine & Denmark & 145 women & & 74 & 26 & 48 & 67 & $\mu \mathrm{g} / \mathrm{L} ; \mathrm{GM}$ & [78] \\
\hline Urine & Denmark & 143 children & & 28 & 39 & 74 & 99 & $\mu \mathrm{g} / \mathrm{L} ; \mathrm{GM}$ & [78] \\
\hline Urine & Denmark & 129 children & & 29 & 111 & & 107 & $\mu \mathrm{g} / \mathrm{L} ;$ median & [79] \\
\hline Urine & Denmark & 441 children & & 16.6 & 80.1 & 72.2 & 89.8 & $\mu \mathrm{g} / \mathrm{L} ;$ median & [80] \\
\hline Urine & Europe & 171 individuals & & 49.9 & 0 & & 4.5 & $\mu \mathrm{g} / \mathrm{g}$ CR; median & [42] \\
\hline Urine & Europe & 1335 children & & 34.4 & 38.4 & 45.4 & 47.6 & $\mu \mathrm{g} / \mathrm{L} ;$ median & [81] \\
\hline Urine & Europe & 1347 mother & & 48.2 & 23.9 & 30.1 & 29.2 & $\mu \mathrm{g} / \mathrm{L} ;$ median & [81] \\
\hline Urine & Europe & 1301 mother & & 72 & 18.3 & 23.3 & 22.4 & $\mu \mathrm{g} / \mathrm{L}$; median & [82] \\
\hline Urine & France & 279 mothers & & 43.5 & 35.7 & 53.7 & 84.6 & $\mu \mathrm{g} / \mathrm{L}$; median & [83] \\
\hline Urine & Germany & 634 individuals & & & 109 & 35.4 & 45.3 & $\mu \mathrm{g} / \mathrm{L}$; median & [84] \\
\hline Urine & Germany & 254 children & & & & & 99.9 & $\mu \mathrm{g} / \mathrm{L} ;$ median & [85] \\
\hline Urine & Germany & 53 women 32 men & & 90.2 & 181 & & 83.3 & $\mu \mathrm{g} / \mathrm{L}$; median & {$[86]$} \\
\hline Urine & Germany & 399 individuals & & & 49.6 & 44.9 & 38.8 & $\mu \mathrm{g} / \mathrm{L} ;$ median & [87] \\
\hline Urine & Germany & 120 females and 120 males & & & 19.6 & 25.5 & 19.3 & $\mu \mathrm{g} / \mathrm{L} ;$ median & [41] \\
\hline Urine & Germany & 30 males and 30 females (2015) & 2.8 & 13.5 & 8.0 & 9.8 & 12.3 & $\mu \mathrm{g} / \mathrm{L} ;$ median & [88] \\
\hline Urine & Germany & 30 males and 30 females (2007) & 8.0 & 53.6 & 16.4 & 19.3 & 33.4 & $\mu \mathrm{g} / \mathrm{L}$; median & [88] \\
\hline Urine & Germany & 111 children ( 48 girls and 63 boys) & & & 53.6 & 74.9 & 130.1 & $\mu \mathrm{g} / \mathrm{L}$; median & [89] \\
\hline Urine & Germany & 465 children (8-10 years old) & & & 52.5 & 62.8 & 75.7 & $\mu \mathrm{g} / \mathrm{L}$; median & [90] \\
\hline Urine & Germany & 599 children & & & 95.6 & 94.3 & 174.6 & $\mu \mathrm{g} / \mathrm{L} ;$ median & [91] \\
\hline Urine & Germany & 600 children (3-14 years old) & & & 96 & & 85 & $\mu \mathrm{g} / \mathrm{L}$; median & [91] \\
\hline Urine & Germany & 207 infants (1-5 month) & & 12.1 & & & 1.1 & $\mu \mathrm{g} / \mathrm{L} ;$ median & [92] \\
\hline Urine & Germany & 104 mothers & & 50.5 & & 66.6 & 28.9 & $\mu \mathrm{g} / \mathrm{L} ;$ median & [93] \\
\hline Urine & Germany & 104 children & & 39.1 & 56.5 & 103.9 & 55.7 & $\mu \mathrm{g} / \mathrm{L} ;$ median & [93] \\
\hline Urine & Greece & 239 women & & 142 & 32.1 & 36.7 & 44.6 & $\mu \mathrm{g} / \mathrm{L} ;$ median & [94] \\
\hline
\end{tabular}


Table 3. Cont.

\begin{tabular}{|c|c|c|c|c|c|c|c|c|c|}
\hline \multirow{2}{*}{ Matrix } & \multirow{2}{*}{ Country/Region } & \multirow{2}{*}{ Studied Population } & \multicolumn{5}{|c|}{ Concentration } & \multirow[b]{2}{*}{ Unit } & \multirow{2}{*}{ Reference } \\
\hline & & & MMP & MEP & MBP & MiBP & MDEHP & & \\
\hline Urine & Greece & 239 children & & 35.3 & 23.3 & 36 & 45.6 & $\mu \mathrm{g} / \mathrm{L} ;$ median & [94] \\
\hline Urine & Hungary & 115 women & ND & 55 & & & 32.4 & $\mu \mathrm{g} / \mathrm{L}$; median & [76] \\
\hline Urine & Hungary & 117 children & ND & 47 & & & 56.7 & $\mu \mathrm{g} / \mathrm{L} ;$ median & [76] \\
\hline Urine & India & 15 women 7 men & 8.6 & 150 & 13 & 18.3 & 77.9 & $\mu \mathrm{g} / \mathrm{L} ;$ median & [72] \\
\hline Urine & Iran & 56 children and adolescent (6-18 years) & 17.4 & 28.2 & 42.9 & & 44.9 & $\mu \mathrm{g} / \mathrm{L} ;$ median & [95] \\
\hline Urine & Ireland & 120 mothers & & 50.2 & 18.5 & 23.8 & 17 & $\mu \mathrm{g} / \mathrm{g}$ CR; GM & [96] \\
\hline Urine & Ireland & 120 children & & 38.7 & 26.1 & 41.4 & 32.8 & $\mu \mathrm{g} / \mathrm{g}$ CR; GM & [96] \\
\hline Urine & Israel & 205 adults (20-74 years old) & & & 27.9 & 37.6 & 81.7 & $\mu \mathrm{g} / \mathrm{L}$; median & [97] \\
\hline Urine & Italy & 83 women (2011) & & 73.1 & 38.8 & & 15.6 & $\mu \mathrm{g} / \mathrm{g}$ CR; median & [42] \\
\hline Urine & Italy & 111 women (2016) & & 49.9 & 0 & & 4.5 & $\mu \mathrm{g} / \mathrm{g}$ CR; median & [42] \\
\hline Urine & Italy & 83 females & & 61.0 & 32.5 & & 10.5 & $\mu \mathrm{g} / \mathrm{L} ;$ median & [98] \\
\hline Urine & Italy & 74 males & & 73.2 & 41.2 & & 15.2 & $\mu \mathrm{g} / \mathrm{L}$; median & [98] \\
\hline Urine & Japan & 8 women 27 men & 18.2 & 16.4 & 17.7 & 7.5 & 35.1 & $\mu \mathrm{g} / \mathrm{L}$; median & [72] \\
\hline Urine & Japan & 80 women (controls) & & 21.4 & 84.3 & & 72.7 & $\mu \mathrm{g} / \mathrm{L} ;$ median & [99] \\
\hline Urine & Japan & 57 women (cases) & & 39.6 & 87.2 & & 89.3 & $\mu \mathrm{g} / \mathrm{L}$; median & [99] \\
\hline Urine & Japan & 35 adults 1 children & 33 & 18 & 36 & & 5 & $\mu \mathrm{g} / \mathrm{L}$; median & [100] \\
\hline Urine & Japan & 111 pregnant women & 5.70 & 7.75 & 46.6 & & 18.5 & $\mu \mathrm{g} / \mathrm{L}$; median & [101] \\
\hline Urine & Korea & 39 children & & 19.2 & 107 & 53.4 & 145.6 & $\mu \mathrm{g} / \mathrm{L}$; median & [102] \\
\hline Urine & Korea & 60 individuals & 10 & 13.4 & 16.7 & 4.5 & 43.6 & $\mu \mathrm{g} / \mathrm{L} ;$ median & [72] \\
\hline Urine & Korea & 25 adults & & 80 & 134 & 40.4 & 125.8 & $\mu \mathrm{g} / \mathrm{L} ;$ median & [103] \\
\hline Urine & Korea & 305 women & & & 41 & & 23.7 & $\mu \mathrm{g} / \mathrm{g}$ CR; median & [104] \\
\hline Urine & Korea & 1646 elderly people & & & 39.5 & & 44.8 & $\mu \mathrm{g} / \mathrm{L} ;$ median & [105] \\
\hline Urine & Korea & 6478 adults & & & 44.2 & & 88.2 & $\mu \mathrm{g} / \mathrm{L}$; median & [106] \\
\hline Urine & Korea & 6003 adults & & & 24.2 & & 52.2 & $\mu \mathrm{g} / \mathrm{L}$; median & [107] \\
\hline Urine & Korea & 171 children & & 2.71 & 12.4 & 5.25 & 12.3 & $\mu \mathrm{g} / \mathrm{L} ;$ median & [108] \\
\hline Urine & Korea & 392 children & & & & & 185 & $\mu \mathrm{g} / \mathrm{L}$; median & [109] \\
\hline Urine & Korea & 265 mothers & & & & & 67.4 & $\mu \mathrm{g} / \mathrm{L}$; median & [109] \\
\hline Urine & Korea & 297 adults & & & & & 55.7 & $\mu \mathrm{g} / \mathrm{L}$; median & [109] \\
\hline Urine & Kuwait & 22 women 24 men & 10.1 & 411 & 113 & 54.1 & 180.4 & $\mu \mathrm{g} / \mathrm{L}$; median & [72] \\
\hline Urine & Malaysia & 19 women 10 men & 6.3 & 18.6 & 10.5 & 10.8 & 27.5 & $\mu \mathrm{g} / \mathrm{L}$; median & [72] \\
\hline Urine & Netherlands & 100 women & ND & 112 & 43.2 & 41.3 & 61.8 & $\mu \mathrm{g} / \mathrm{L}$; median & [110] \\
\hline Urine & Norway & 10 women & 2 & 310 & 41.1 & 57 & 112.3 & $\mu \mathrm{g} / \mathrm{L}$; median & [111] \\
\hline Urine & Norway & 61 adults & & 24.2 & 13.4 & 12.8 & & $\mu \mathrm{g} / \mathrm{L}$; median & [112] \\
\hline Urine & Norway & 116 pregnant women & & 55 & 25 & 20 & 26 & $\mu \mathrm{g} / \mathrm{L}$; median & [113] \\
\hline Urine & Portugal & 112 children (4-18 years) & & 59.4 & 12.7 & 16.9 & 40.4 & $\mu \mathrm{g} / \mathrm{L} ;$ median & [114] \\
\hline Urine & Saudi Arabia & 130 individuals & 8.65 & 47.5 & 38.5 & 38.5 & 117.1 & $\mu \mathrm{g} / \mathrm{L}$; median & [26] \\
\hline Urine & Slovakia & 129 occupational exposure & & & 110 & 39.2 & 55.9 & $\mu \mathrm{g} / \mathrm{L} ;$ median & [115] \\
\hline Urine & Slovakia & 68 occupational exposure population & & 201 & 103 & 61.4 & 82.7 & $\mu \mathrm{g} / \mathrm{L} ;$ median & [116] \\
\hline Urine & Slovakia & 125 women & ND & 54.8 & & & 36.7 & $\mu \mathrm{g} / \mathrm{L}$; median & [76] \\
\hline Urine & Slovakia & 127 children & ND & 39.6 & & & 82.8 & $\mu \mathrm{g} / \mathrm{L}$; median & [76] \\
\hline Urine & Slovakia & 85 occupational exposure & & 78.5 & 85.6 & & 21.5 & $\mu \mathrm{g} / \mathrm{L}$; median & [117] \\
\hline Urine & Slovakia & 70 general population & & 78.1 & 96 & & 14.7 & $\mu \mathrm{g} / \mathrm{L} ;$ median & [117] \\
\hline
\end{tabular}


Table 3. Cont.

\begin{tabular}{|c|c|c|c|c|c|c|c|c|c|}
\hline \multirow{2}{*}{ Matrix } & \multirow{2}{*}{ Country/Region } & \multirow{2}{*}{ Studied Population } & \multicolumn{5}{|c|}{ Concentration } & \multirow[b]{2}{*}{ Unit } & \multirow{2}{*}{ Reference } \\
\hline & & & MMP & MEP & MBP & MiBP & MDEHP & & \\
\hline Urine & Spain & 391 pregnant women & & 246 & 27.1 & 28.4 & 87.8 & $\mu \mathrm{g} / \mathrm{L} ;$ median & [118] \\
\hline Urine & Spain & 120 children & & 198.9 & & & 63 & $\mu \mathrm{g} / \mathrm{g}$ CR; GM & [119] \\
\hline Urine & Spain & 120 mothers & & 150.8 & & & 33.3 & $\mu \mathrm{g} / \mathrm{g}$ CR; GM & [119] \\
\hline Urine & Sweden & 314 men & & 41 & 47 & & 48.4 & $\mu \mathrm{g} / \mathrm{L} ;$ median & [120] \\
\hline Urine & Sweden & 38 women & 1.2 & 35 & 46 & 16 & 35 & $\mu \mathrm{g} / \mathrm{L} ;$ median & [24] \\
\hline Urine & Taiwan & 41 women and 19 men (21-67 years) & 32.3 & & 36.5 & & 15.9 & $\mu \mathrm{g} / \mathrm{L} ;$ median & \\
\hline Urine & Taiwan & 155 women & 5.7 & 25.3 & 80 & & 22.6 & $\mu \mathrm{g} / \mathrm{L} ;$ median & \\
\hline Urine & Taiwan & 30 (children, age: 2) & & & 100.4 & 17.2 & 195.8 & $\mu \mathrm{g} / \mathrm{L} ;$ median & [121] \\
\hline Urine & Taiwan & 59 (children, age: 5) & & & 75.2 & 25.2 & 148.9 & $\mu \mathrm{g} / \mathrm{L} ;$ median & \\
\hline Urine & Taiwan & 100 women & & & 72.3 & 12.5 & 96.8 & $\mu \mathrm{g} / \mathrm{L} ;$ median & \\
\hline Urine & U.S. & 45 males (subfertile couples) & & 108 & 24.7 & & 91.4 & $\mu \mathrm{g} / \mathrm{L} ;$ median & [122] \\
\hline Urine & U.S. & 35 children & & 177.7 & 52.4 & 16.6 & 1025.9 & $\mu \mathrm{g} / \mathrm{L} ;$ median & [123] \\
\hline Urine & U.S. & $7600-10,031$ individuals & 1.4 & 167 & 18.9 & 3.6 & 73.1 & $\mu \mathrm{g} / \mathrm{g}$ CR; median & [124] \\
\hline Urine & U.S. & $12-18$ months toddlers & & $13.2-1388$ & $6.6-2540$ & & $<1.7-47.3$ & $\mu \mathrm{g} / \mathrm{L} ;$ median & [125] \\
\hline Urine & U.S. & 186 persons in Northern Manhattan & & 199 & 36 & & & $\mu \mathrm{g} / \mathrm{L} ;$ median & [126] \\
\hline Urine & U.S. & 446 pregnant women & & 41.1 & & & & $\mu \mathrm{g} / \mathrm{g}$ CR; GM & [127] \\
\hline Urine & U.S. & 378 pregnant women & & 47 & 13.7 & 9.47 & 14 & $\mu \mathrm{g} / \mathrm{L} ;$ median & [128] \\
\hline Urine & U.S. & 482 individuals & & 141 & 17.8 & 7.6 & 106.6 & $\mu \mathrm{g} / \mathrm{L} ;$ median & [27] \\
\hline Urine & U.S. & 2772 adults & & 167 & & & 35.4 & $\mu \mathrm{g} / \mathrm{g}$ CR; median & [129] \\
\hline Urine & U.S. & 392 children of $6-11$ years old & & 96.9 & & & 69.9 & $\mu \mathrm{g} / \mathrm{g}$ CR; median & [129] \\
\hline Urine & U.S. & 2350 individuals & 1.8 & 194.4 & 20.7 & 3.7 & 73 & $\mu \mathrm{g} / \mathrm{L} ;$ median & [130] \\
\hline Urine & U.S. & 33 lactating women & & & & & $35.7-45.9$ & $\mu \mathrm{g} / \mathrm{L} ;$ median & [131] \\
\hline Urine & U.S. & 50 pregnant women (18-38) & & 61.5 & 18.2 & & 31.1 & $\mu \mathrm{g} / \mathrm{L} ;$ median & [132] \\
\hline Urine & U.S. & 406 men & 4.5 & 145 & 14.5 & & 5.2 & $\mu \mathrm{g} / \mathrm{L} ;$ median & [133] \\
\hline Urine & Vietnam & 16 women 14 men & 8.4 & 7.2 & 19.1 & 13.6 & 56.7 & $\mu \mathrm{g} / \mathrm{L} ;$ median & [72] \\
\hline Serum & Denmark & 60 men & & $<\mathrm{LOD}$ & ND & $<$ LOD & 8.4 & $\mu \mathrm{g} / \mathrm{L} ;$ median & [77] \\
\hline Serum & Sweden & 36 women & & 0.5 & 0.5 & 0.5 & 0.5 & $\mu \mathrm{g} / \mathrm{L} ;$ median & [24] \\
\hline Seminal plasma & Denmark & 60 men & & $<\mathrm{LOD}$ & $<$ LOD & ND & $<\mathrm{LOD}$ & $\mu \mathrm{g} / \mathrm{L} ;$ median & [77] \\
\hline Breast milk & Denmark & 65 women & 0.1 & 0.9 & 4.3 & & 9.5 & $\mu \mathrm{g} / \mathrm{L}$; median & [25] \\
\hline Breast milk & Finland & 65 women & 0.1 & 1.0 & 12.0 & & 13.0 & $\mu \mathrm{g} / \mathrm{L} ;$ median & [25] \\
\hline Breast milk & Sweden & 42 women & & ND & 0.5 & ND & $0.49)$ & $\mu \mathrm{g} / \mathrm{L} ;$ median & [24] \\
\hline Milk & Switzerland & 54 women & & & 6.0 & 24.3 & 26.2 & $\mu \mathrm{g} / \mathrm{L} ;$ median & [134] \\
\hline Milk & U.S. & 33 lactating women & & & & & $0.3-0.7$ & $\mu \mathrm{g} / \mathrm{L} ;$ median & [131] \\
\hline Nail & Belgian & 10 individuals & & 64 & 74 & & 138 & $\mu \mathrm{g} / \mathrm{g}$ CR; median & [135] \\
\hline Nail & Norway & 61 adults & 89.7 & 104.8 & 89.3 & & & $\mu \mathrm{g} / \mathrm{g}$ CR; GM & [112] \\
\hline
\end{tabular}

MDEHP: Sum of five DEHP metabolites (MEHP, MEHHP, MEOHP, MECPP, and MCMHP); ND: Not detected; LOD: Limit of detection; LOQ: Limit of quantification; GM = Geometric mean; $\mathrm{CR}=$ Creatinine. 
Phthalate diesters (parent compounds) were measured in blood plasma of women with endometriosis in India, and a significant association was found between phthalate exposure and the risk of developing endometriosis [136]. Similarly, studies have determined phthalates in serum samples of couples from Greenland, Poland, and Ukraine that showed that the DEHP levels were associated with reduced time to achieve pregnancy [137]. Phthalate diesters and their metabolites also have been measured in breast milk, serum, and urine from Swedish women [24]. In milk and serum samples, the concentrations of phthalate diesters and their metabolites were below the method limit of detection $(0.12-3.0 \mu \mathrm{g} / \mathrm{L})$. Detectable concentrations of phthalate metabolites, however, were found in urine $(0.1-1000 \mu \mathrm{g} / \mathrm{L})$. Measurements of phthalate diesters in breast milk and serum are prone to false positives due to background contamination. Medical devices, including blood collection devices and plastic containers that are used to collect and store samples, can contain phthalate diesters [49]. If the samples were to be analyzed for phthalate diesters, caution should be taken with the screening devices used to collect and store samples. A comprehensive review of challenges associated with low-level phthalate analysis in biological specimens has been published [17].

\subsection{Phthalate Metabolites in Urine}

Although microbial degradation of DEHP to MEHP in soils through lipase and esterase enzymes has been shown, environmental degradation/transformation of parent phthalates is slow $[25,138]$. Because phthalates have a short half-life in human bodies and are excreted quickly in urine as monoester metabolites, the metabolites are suitable biomarkers for human exposure to parent compounds. The half-life of phthalates in human bodies (in plasma and urine) is less than $24 \mathrm{~h}$, and following metabolism, monoesters of phthalates are conjugated with glucuronide or sulfate and excreted in urine [139]. Analysis of metabolites in urine involves enzymatic deconjugation followed by purification. Assessment of human exposure to phthalates is based mainly on the measurement of their urinary monoester metabolites, although several secondary and oxidative metabolites have been reported to occur in human specimens [139]. For instance, DMP, DEP, and DBP undergo degradation/hydrolysis and form their corresponding monoesters, i.e., MMP, MEP and MBP, respectively. Both hydrolysis and oxidation products are formed from the metabolism of DEHP. MEHP, the hydrolysis product of DEHP, is not a major metabolite. The oxidative metabolites, MEOHP, MEHHP, MECPP, and MCMHP, however, are the major metabolites of DEHP and are appropriate biomarkers of exposure to this compound [21]. Some studies suggest, however, that MEHP is more toxic than are other oxidative metabolites. The general metabolic pathways of phthalate esters in humans are shown in Figure 2.

General Population Adults: A large number of studies have reported measurements of phthalate metabolites in human specimens collected from European (Germany, Netherlands, Denmark, Norway, Sweden, Greece, the Czech Republic, Hungary, Slovakia, and Spain) and Asian countries (Japan, China, South Korea, India, Taiwan, Vietnam, Saudi Arabia, Malaysia, and Kuwait) as well as from North American countries. The number of phthalate metabolites measured in urine samples varied considerably; as new analytical standards become made available commercially, more metabolites were added to the list of compounds measured in urine. Although a majority of the recent studies measure close to 20 phthalate metabolites, studies conducted a decade ago measured 10 or fewer metabolites of phthalates.

In general, the concentrations of the sum of 22 phthalate metabolites measured in human urine were on the order of several to hundreds of parts-per-billion $(\mu \mathrm{g} / \mathrm{L})$ [21]. In a majority of the biomonitoring studies, metabolites of DEHP, DEP, and DBP were the major compounds identified in urine, and the profile varied depending on the country. Urine samples collected from 32 men and 53 women (age: 7-64 years) from northern Bavaria (Germany) contained MBP (median: $181 \mu \mathrm{g} / \mathrm{L}$ ), MEP $(90.2 \mu \mathrm{g} / \mathrm{L})$, and major DEHP metabolites, such as MEHHP $(46.8 \mu \mathrm{g} / \mathrm{L})$ and MEOHP $(36.5 \mu \mathrm{g} / \mathrm{L})$ [86]. The median concentrations of DEHP metabolites, namely, MEHP, MEOHP, and MEHHP, were 4.5, 28.3, and $35.9 \mu \mathrm{g} / \mathrm{L}$, respectively, and these three metabolites were highly intercorrelated. The concentration 
ratios, MEHHP/MEHP, and MEOHP/MEHP, were calculated to be 8.2, and 5.9, respectively. These ratios suggest that MEHP is further oxidized to form MEHHP and MEOHP [86].

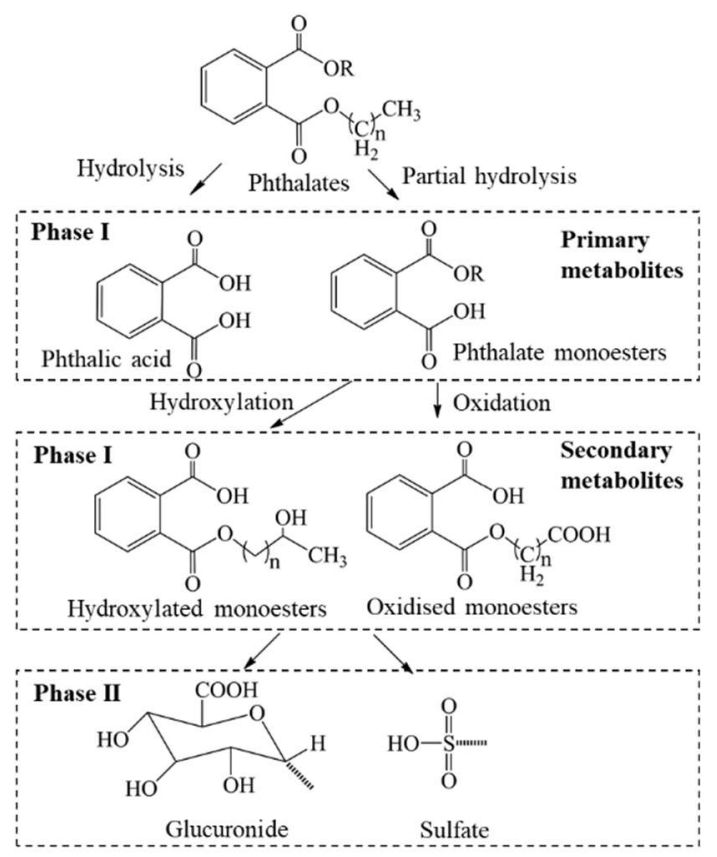

Figure 2. Metabolic pathways of phthalate esters in humans.

The urinary concentrations of phthalate metabolites in general populations vary among countries. Some of the highest concentrations of total phthalate metabolites were found in urine collected in 2006-2007 from Kuwaitis, with a maximum value of 19,300 $\mu \mathrm{g} / \mathrm{L}$ and a median value for of $1050 \mu \mathrm{g} / \mathrm{L}$ [72]. The occurrence of phthalate metabolites was investigated in urine from Germans, and MBP was found at high concentrations (median: $49 \mu \mathrm{g} / \mathrm{L}$ ) [87]. The median concentrations of phthalate metabolites in urine samples from Germany decreased significantly from 2002 to 2008 [41]. Similarly, urinary phthalate metabolites measured in 2015 were significantly lower than those in 2007 in Germany [88].

Biomonitoring studies in other European countries, including France [83], Belgium $[65,66]$, Slovakia [117], and Norway [112], report phthalate metabolite concentrations in the range of 1-100 $\mu \mathrm{g} / \mathrm{L}$ in urine from adults. MBP and DEHP metabolites were the predominant compounds found in those studies. Further, a comparative analysis of biomonitoring data in Europe suggested a significant decline in phthalate metabolite concentrations (especially MEP, MBP, MBzP, and DEHP metabolites) from 2011 to 2016 [42]. Several alternative plasticizers, however, are used as replacements for DEHP in European countries. Common alternatives include Hexamoll DINCH (DINCH), acetyl tributyl citrate (ATBC), dioctyl terephthalate (DOTP), 2,2,4-trimethyl 1,3-pentanediol diisobutyrate (TXIB), trioctyl trimellitate (TOTM), and di-(2-ethylhexyl) adipate (DEHA).

In North America, the distribution of phthalate metabolites in urine has been summarized in nationwide monitoring surveys. For example, the US National Health and Nutrition Examination Survey (NHANES) of the Centers for Disease Control and Prevention (CDC) showed that MEP, MEHP, MEHHP, and MEOHP concentrations in urine from adults $>20$ years of age were 167, 3.99, 18.8, and $12.6 \mu \mathrm{g} / \mathrm{g}$ creatinine (CR), respectively [129]. The NHANES program has measured 15 phthalate metabolites in urine. The weighted geometric mean concentration of 15 phthalate metabolites in the US general population was $125 \mu \mathrm{g} / \mathrm{L}$ for the samples collected in the period of 2007-2008. MEP was the major compound found in urine, accounting for $>70 \%$ of the total concentrations, which was followed by mono-(2-ethyl-5-hydroxyhexyl) phthalate (MEHHP; $18 \%$ of the total phthalate concentrations). The NHANES data for the US general population in the period of 2005-2006 showed that MCNP, a metabolite of DiDP, was found at a median concentration of $2.70 \mu \mathrm{g} / \mathrm{L}$ [140]. The updated NHANES 
report for 2013-2014 are available (https://wwwn.cdc.gov/Nchs/Nhanes/2013-2014/SSPHTE_H.htm). A 67\% decline in DEHP exposure in the US population between 2005/6 and 2011/12 has been reported [141]. Several factors have been shown to affect exposures. The NHANES data showed that several phthalate urinary metabolites were higher in males, Hispanics, and African Americans [142]. The Human Biomonitoring Program of Health Canada measured 11 phthalate metabolites in urine samples of 3236 Canadians and found median MEP and MEHHP concentrations at 49.1 and 23.4 $\mu \mathrm{g} / \mathrm{L}$, respectively [68]. Since 2001, there has been clear evidence of a decline in DEP, DBP, and DEHP exposure in the US [115]. In contrast, urinary DiNP concentrations in the US population increased significantly during the period 2005/6-2011/12 (www.cdc.gov/exposurereport).

Urinary concentrations of phthalate metabolites have been reported for several Asian countries [97]. The measured concentrations in Asian countries were similar to those reported in Europe and North America, although the profiles were distinct. For instance, MBP and MiBP were the major metabolites found in urine from China, and their respective median concentrations were 61.2 and $51.7 \mu \mathrm{g} / \mathrm{L}$ [51]. Similar concentrations of MBP and the sum of DEHP metabolites were reported in urine from Nanjing city (47.1 and $42.0 \mu \mathrm{g} / \mathrm{L})$ [74] and Taiwan (47.1 and $42.0 \mu \mathrm{g} / \mathrm{L})$ [121]. In contrast, DEHP metabolites were predominant in urine from Japan, Malaysia, and Vietnam [72]. A nationwide survey of urine samples from 6478 adults during the period of 2012-2014 in Korea showed median urinary concentrations of DEHP metabolites $(88.2 \mu \mathrm{g} / \mathrm{L})$ that were twofold higher than that of MBP $(44.2 \mu \mathrm{g} / \mathrm{L})[106,107]$. In Israel, phthalate metabolites were found in urine samples collected from 250 adults (ages 20-74), with median concentrations that ranged from $17.1 \mu \mathrm{g} / \mathrm{L}$ (MEOHP) to $37.6 \mu \mathrm{g} / \mathrm{L}$ (MiBP) [97]. DEHP exposure in the Chinese population has increased since 2001 [143].

The global distribution of major phthalate metabolites measured in urine from general populations is presented in Figure 3. Urine samples collected from Kuwait during 2006-2007 contained the highest median concentrations of MEP $(411 \mu \mathrm{g} / \mathrm{L})$, MBP $(113 \mu \mathrm{g} / \mathrm{L})$, and DEHP metabolites $(180 \mu \mathrm{g} / \mathrm{L})$, with a sum of median phthalate metabolite concentrations (median) at 1,050 $\mu \mathrm{g} / \mathrm{L}$ [72]. This value is the highest among all countries studied. The profiles of phthalate metabolites varied, with MEP as the predominant metabolite in Indian and Kuwaiti urine samples (49\% of the total), which were similar to those found in the US. In China (52\%), MBP was the major metabolite found in urine. In Korea (46\%), Japan (31\%), and Vietnam (52\%), DEHP metabolites were the dominant ones. MMP accounted for $<8 \%$ of the total phthalate metabolite concentrations in all Asian countries, except for Japan, where it was $20 \%$. Overall, MEP and DEHP metabolites were the major phthalate metabolites found in urine from most Asian countries, a pattern similar to that found in the US [130]. The reported urinary concentrations of phthalate metabolites among several European countries were similar whereas information for African countries and Australia/Oceanian countries is limited.

Pregnant Women: Phthalates have been widely studied for exposure levels in pregnant women. MEP $(222 \mu \mathrm{g} / \mathrm{g} \mathrm{CR})$ was the predominant phthalate metabolite found in urine samples of pregnant women from the Netherlands (Generation R study) [110]. Similar exposure levels were reported for pregnant women from the US [131,132], Canada [69], and Norway [113], with MEP median concentrations exceeding $30 \mu \mathrm{g} / \mathrm{L}$. In a study of urinary phthalate metabolite concentrations in Spanish pregnant women $(n=391)$, the median concentration of MEP was reported at $246 \mu \mathrm{g} / \mathrm{g}$ CR [118].

Several studies have examined phthalate metabolite concentrations in matched urine samples of newborns and mothers. Maternal urinary concentrations of MEHHP and MEOHP in Korea were 17.7 and $14.7 \mu \mathrm{g} / \mathrm{L}$, respectively, which were two- to threefold higher than those found in newborns (5.79 and $3.27 \mu \mathrm{g} / \mathrm{L}$ ) [144]. Another study, however, showed similar urinary concentrations of phthalate metabolites between 120 mother-and-child pairs [96]. Occurrence of phthalate metabolites in pregnant women suggests potential exposure in the fetus. 


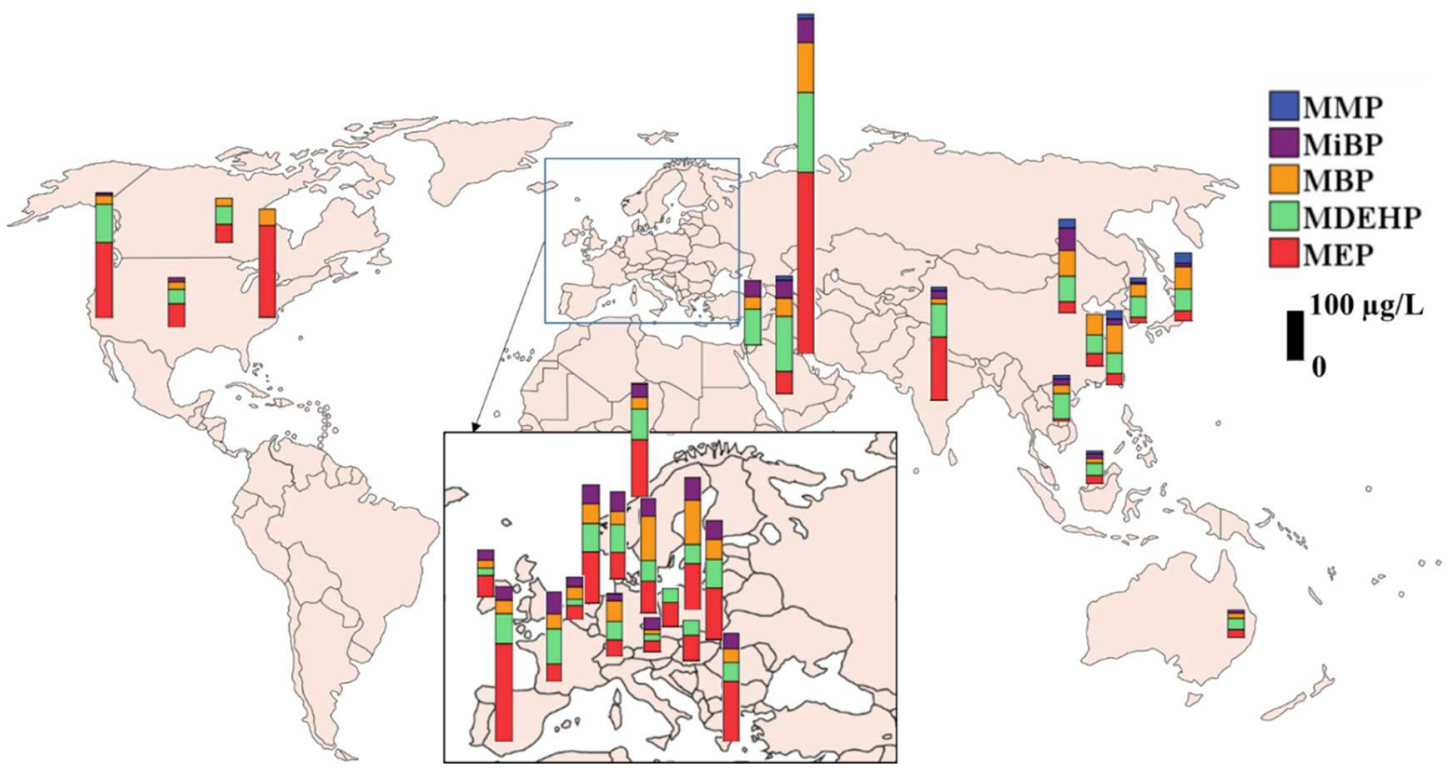

Figure 3. Urinary concentrations of phthalate metabolites reported in adults (general population) from several countries (MDEHP: Sum of DEHP metabolites; biomonitoring data published after 2000; median concentration is presented).

Children: The NHANES data showed that the concentrations of urinary phthalate metabolites in children 6-11 years old were higher than those in adolescents and adults [142]. Several studies support the CDC's findings that children have higher urinary concentrations than do adults of DBP, BzBP, and DEHP [41,145]. Differences in urinary concentrations of phthalates among infants, children, and adults may reflect different sources and routes of intake. Ingestion is thought to be a primary pathway of exposure to some phthalates, especially those in food packaging [146]. The mouthing behavior of infants and toddlers could potentially increase their exposures to phthalates in toys and other products made with plasticized polymers. The global distribution of reported urinary phthalate metabolite concentrations in children is shown in Figure 4.

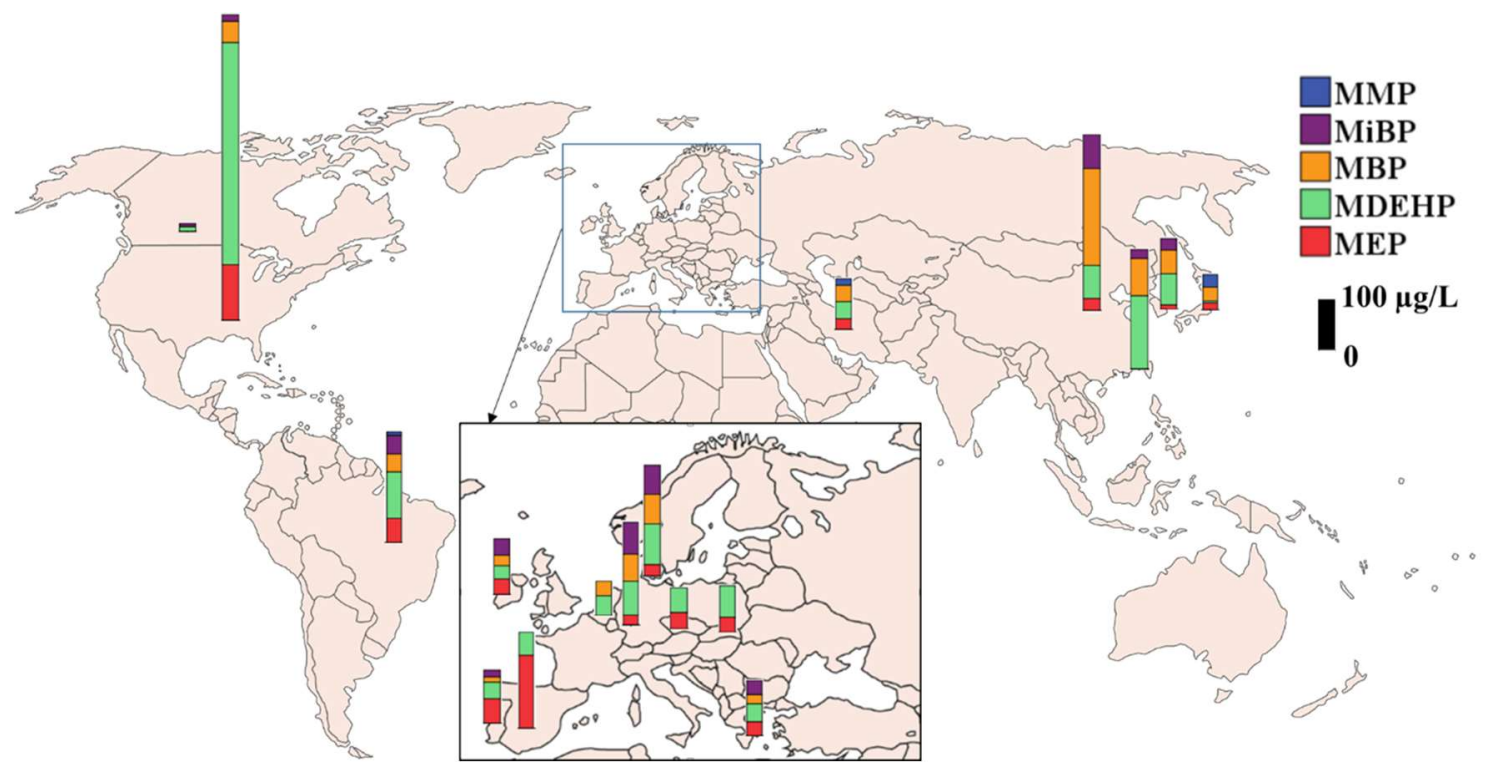

Figure 4. Urinary concentrations of phthalate metabolites reported in children (general population) from several countries (MDEHP: Sum of DEHP metabolites; biomonitoring data published after 2000, median concentration is presented). 
MEP, MBP, and DEHP metabolites were the dominant compounds detected in urine from children. Spot urine samples from 5- to 7-year-old German children contained a median phthalate metabolite concentration (sum of 5 metabolites) of $76.9 \mu \mathrm{g} / \mathrm{L}$, with DEHP metabolites as major compounds [89]. A similar concentration of DEHP metabolites at $75.7 \mu \mathrm{g} / \mathrm{L}$ was found in urine samples from 8- to 10-year-old German children $(n=465)$ [90]. Several biomonitoring studies reported comparable concentrations of DEHP metabolites and MBP in urine from children in China [75], Korea [108], Canada [70], Brazil [67] and Portugal [114].

In urine samples collected from children in Beijing, China, MBP was the most abundant metabolite (median: $232 \mu \mathrm{g} / \mathrm{L})$, followed by MiBP $(81.3 \mu \mathrm{g} / \mathrm{L})$, MECPP $(79.1 \mu \mathrm{g} / \mathrm{L})$, and MEP $(28.5 \mu \mathrm{g} / \mathrm{L})$. A significant association between the concentrations of parent phthalate diesters in handwipes and the corresponding monoester metabolites in urine were observed in urine from children, which suggested that dermal absorption is an important exposure pathway for phthalates in children [75]. Mean urinary concentrations of MBP decreased as the children aged [91]. Among children, urinary DBP and DEHP metabolites in boys were higher than those in girls, whereas urinary MEP concentrations were positively correlated with age in both genders [79]. Urinary concentrations of MEP in adolescents were higher than those in children, which was associated with high cosmetic usage among teenagers $[79,95]$.

Urinary phthalate metabolite concentrations have been reported for children and adults from 17 European countries, namely, Belgium, Cyprus, Czech Republic, Denmark, Germany, Hungary, Ireland, Luxembourg, Poland, Portugal, Romania, Slovenia, Slovak Republic, Spain, Sweden, Switzerland, and the United Kingdom (DEMOCOPHES); the geometric mean concentrations of MEP, MBZP, MBP, MiBP, and $\Sigma$ DEHP metabolites were 34.4, 7.15, 34.8, 45.4, and $47.6 \mu \mathrm{g} / \mathrm{L}$ for children $(n=1355)$ and were $48.2,4.51,23.9,30.1$, and $29.2 \mu \mathrm{g} / \mathrm{L}$ for mothers [81], which suggested that children in those countries were more highly exposed to several phthalates than were their mothers. Nevertheless, some studies reported higher urinary MEP concentrations in mothers $(45.1-72.0 \mu \mathrm{g} / \mathrm{L})$ than in children (12.1-16.4 $\mu \mathrm{g} / \mathrm{L})$ [82,92]. The concentrations of DEHP metabolites were reported to be similar between mothers and children $[82,109,119]$. A significant positive correlation existed in urinary phthalate metabolite concentrations between children and their parents. MECPP, an oxidative metabolite of DEHP, was predominant in urine from children (92.7\%) relative to that found in adults (56.7-57.6\%). Studies have found that children possess enhanced oxidative metabolism for DEHP $[91,109,147]$. Another study of urinary phthalate metabolites in 104 paired mothers and school-aged children reported higher concentrations of secondary DEHP metabolites in children than in mothers [93]. A study from Austria showed higher urinary concentrations of phthalate metabolites in children than adults [62]. Overall, these studies suggest higher exposures to phthalates in children than adults.

Highly Exposed Populations: Highly exposed individuals have urinary phthalate metabolite concentrations that often exceed those at the 95th percentile of the general population (https://www. ncbi.nlm.nih.gov/books/NBK215044/). Neonates who receive medical treatments such as transfusions are widely recognized as potentially highlexposed [148]. A study from Slovakia showed that the urinary concentrations of DEHP metabolites, MiBP, and MBP in occupationally exposed individuals from plastic industry were 55.9, 39.2, and $110 \mu \mathrm{g} / \mathrm{L}$, respectively [115], which were higher than those in urine from women of no known occupational exposures [61]. The median concentrations of MEP, MBP, MiBP, and DEHP metabolites in urine from hairdressing apprentices who attended vocational training schools in Slovakia were 201, 103, 61.4, and $82.7 \mu \mathrm{g} / \mathrm{L}$, respectively [116]. Some medications contain phthalates in their coatings or delivery systems [49] and may contribute to the high exposures of children, pregnant women, and others who take these medications.

Exposure Assessment: The concentrations of phthalate metabolites measured in urine can be used to assess the amount of parent phthalate to which humans are exposed, when the fraction of the metabolite excreted in urine is known, as presented in the equation below [147]:

$$
\text { Estimated parent phthalate concentration }=\frac{\text { Metabolite concentration }}{\text { Excretion fraction }}
$$


The estimated daily intake (EDI) of parent phthalates is then calculated by taking the average weight of an individual with the average urinary excretion rate, as shown in the equation below:

Estimated daily intake $(\mathrm{EDI})=\frac{\text { Estimated parent phthalate concentration } \times \text { Daily urine excretion volume }}{\text { Average body weight }}$

Several studies have estimated exposure doses to phthalates in populations, which allowed for comparison against a reference dose $(R f D)$, the maximum acceptable oral dose of a toxic substance, of the US EPA. The estimated mean daily exposure doses to DEP and DBP in Asian countries and the US were one to two orders of magnitude below the EPA RfD (DEP $=800, \mathrm{DBP}=100$, and DEHP $=20 \mu \mathrm{g} / \mathrm{kg}$ body weight (bw)/day). The estimated daily exposure doses to DEHP in Kuwait and India, however, were close to the RfD of the US EPA [72]. Similarly, high concentrations of DEHP metabolites (mean concentration $=338 \mu \mathrm{g} / \mathrm{L}$ ) were reported in urine from the Saudi population [26].

The calculated $E D I_{\max }$ values for DEHP and DBP were 8 and $0.08 \mu \mathrm{g} / \mathrm{kg}$ bw/day, respectively, for the population in Taiwan, which were one to two orders of magnitude lower than the tolerable daily intake (TDI) values (the daily intake amount of a chemical that has been assessed to be safe for human being on a long-term basis) suggested for DEHP ( $50 \mu \mathrm{g} / \mathrm{kg} \mathrm{bw})$ and DBP $(10 \mu \mathrm{g} / \mathrm{kg} \mathrm{bw})$ by the European Food Safety Authority (EFSA) [147].

The 95th percentile for DEHP exposure doses calculated for the general population $(n=85)$ and children $(n=254)$ from Germany were 21 and $25 \mu \mathrm{g} / \mathrm{kg}$ bw/day, respectively, which exceeded the RfD ( $20 \mu \mathrm{g} / \mathrm{kg}$ bw/day) and the TDI (20-48 $\mu \mathrm{g} / \mathrm{kg}$ bw/day) [149]. Further, elevated exposure to phthalates, especially DEHP, in neonates admitted to intensive care units was reported (median: $42 \mu \mathrm{g} / \mathrm{kg}$ bw/day; 95th percentile: $1780 \mu \mathrm{g} / \mathrm{kg}$ bw/day) [149], and the exposure dose was higher than the RfD.

Some studies defined "Biomonitoring Equivalents (BEs)" as the concentration or range of concentrations of a chemical or its metabolite in a biological medium (blood, urine, or other medium) that is consistent with an existing health-based exposure guideline (e.g., RfD and TDI) [150,151]. BE values for MBP, MBzP, and MEP were reported at 18000, 3800 and $2700 \mu \mathrm{g} / \mathrm{L}$, respectively [150], and the BE values range from 1500 to $3600 \mu \mathrm{g} / \mathrm{L}$ for MiNP [151]. These values may be used as screening tools for evaluation of biomonitoring data for phthalate metabolites in the context of existing risk assessments and for prioritization of the potential need for additional risk assessment efforts for each of these compounds relative to other chemicals [150,151].

Although current exposure doses in the general population are below the tolerance limits reported by environmental agencies, certainly population groups, especially children, are exposed to high levels of phthalates. Studies of the effects of phthalates from early life stage exposures are warranted.

\subsection{Phthalate Metabolites in Serum}

The biomonitoring studies of human phthalate exposure have been based on urinary concentrations of phthalate metabolites. However, when only serum was available for analysis, MEP and MiBP representing low molecular weight phthalates, and MECPP and MCiOP representing high molecular weight phthalates, have been used as indicators of phthalate exposure [77]. A study reported the correlations of phthalate metabolite concentrations among urine, serum, and seminal plasma of young Danish men [77]. The mean concentrations of MEP, MBP, and DEHP metabolites were one to two orders of magnitude lower in serum (MEP: 4.2, MBP: 0.4, and DEHP: $7.6 \mu \mathrm{g} / \mathrm{L}$ ) and seminal plasma $(1.0,0.8$, and $0.6 \mu \mathrm{g} / \mathrm{L})$ than in urine $(326,42.5$, and $115 \mu \mathrm{g} / \mathrm{L})$. Another study, however, showed that the distribution pattern of monoester metabolites in serum was similar to that of urine [152], especially for MEHP (the metabolite of DEHP) [152]. Nevertheless, MEHHP, MEOHP, MECPP, and MCMHP were found at much higher concentrations in urine than in serum [153]. The presence of MEHP in serum was more likely related to contamination that arises from sampling devices.

Whole blood and cord blood samples from 128 healthy pregnant women and their newborns were analyzed for phthalate metabolites. Median concentrations of MEHHP and MEOHP were 0.31 and $<\mathrm{LOD} \mu \mathrm{g} / \mathrm{L}$ in maternal blood and 0.32 and $<\mathrm{LOD} \mu \mathrm{g} / \mathrm{L}$ in cord blood, respectively. MEHHP and 
MEOHP also were reported to occur in the placenta at concentrations of 0.09 and <LOD ng/g [144]. MBP, MEHP, MEP, and MiBP were detected in blood serum at median concentrations of $0.540 .49,0.50$, and $0.5 \mu \mathrm{g} / \mathrm{L}$, respectively [24], and these concentrations were at least an order of magnitude lower than those measured in urine.

In the serum of patients who were undergoing dialysis [53,154-156], phthalate acid (PA) was found as a metabolite of phthalates at remarkably high concentrations of $5.22 \pm 3.94 \mathrm{mg} / \mathrm{L}$ [155]. Another study also reported the occurrence of PA in serum $(0.205 \pm 0.067 \mathrm{mg} / \mathrm{L})$ of patients who were undergoing dialysis [154]. Accumulation of PA in patients who are undergoing dialysis has been suggested [156]. Serum concentrations of MEHP and DEHP were reported in autistic children [157].

\subsection{Phthalate Metabolites in Amniotic Fluid, Breast Milk, Semen, and Saliva}

MBP was found in $>93 \%$ of amniotic fluid samples collected from the US [59] at concentrations two- to threefold lower than those of serum and four- to sevenfold lower than those of urine [59]. Studies have reported the occurrence of phthalates in breast milk [158]; the reported concentrations in breast milk were much lower than those in urine but similar to those in amniotic fluid. Monoester metabolites of phthalates were measured in breast milk from 33 lactating mothers in North Carolina. $\operatorname{MCPP}(0.2 \mu \mathrm{g} / \mathrm{L})$ and MEOHP $(0.3 \mu \mathrm{g} / \mathrm{L}), \operatorname{MECPP}(0.1-0.4 \mu \mathrm{g} / \mathrm{L})$, and MEHHP $(0.2-0.3 \mu \mathrm{g} / \mathrm{L})$ were detected in some samples [131]. MiNP was the major metabolite found in breast milk collected from mothers in Denmark $(101 \mu \mathrm{g} / \mathrm{L})$ and Finland $(89 \mu \mathrm{g} / \mathrm{L})$ [25,159]. Median concentrations of MBP, MBzP, and MEHP in breast milk were $0.54,0.50$, and $0.49 \mu \mathrm{g} / \mathrm{L}$, respectively [24].

Human saliva samples $(n=39)$ also contained phthalate metabolites $[57,160]$. Salivary concentrations of phthalate metabolites in 39 adult volunteers were in the ranges of $<1$ to $10.6 \mu \mathrm{g} / \mathrm{L}$ for PA, $91.4 \mu \mathrm{g} / \mathrm{L}$ for MEP, $65.8 \mu \mathrm{g} / \mathrm{L}$ for MBP, and $354 \mu \mathrm{g} / \mathrm{L}$ for MBzP. MBP was the most (85\%) frequently detected compound in saliva [57]. Two phthalate metabolites $(2.2 \mu \mathrm{g} / \mathrm{L} \mathrm{MCPP}$ and $2.3 \mu \mathrm{g} / \mathrm{L} \mathrm{MECPP})$ were detected in a saliva sample from a US woman [131].

MBP and MBzP were found in semen from US men [32,54]. High concentrations of DEHP and its metabolites $\left(\sum 40.6 \mu \mathrm{g} / \mathrm{L}\right)$ were found in semen from German men [161]. Studies have also indicated that semen quality can be affected by environmentally relevant phthalate exposures [121]. Further, DEHP $(4.20 \mu \mathrm{g} / \mathrm{L})$ and DBP $(2.06 \mu \mathrm{g} / \mathrm{L})$ were reported at high concentrations in male seminal plasma from men in the US. The metabolites of DEHP $\left(\sum 0.98 \mu \mathrm{g} / \mathrm{L}\right)$ and MBP $(2.97 \mu \mathrm{g} / \mathrm{L})$ also were present in considerable concentrations in seminal plasma in the same study [162]. These results suggested that phthalate metabolites can partition in seminal plasma. Similarly, DEHP $(2.09 \mu \mathrm{g} / \mathrm{L})$ and DBP $(1.75 \mu \mathrm{g} / \mathrm{L})$, as well as their metabolites, were found as the predominant phthalates/phthalate metabolites in seminal plasma from male partners who were planning for pregnancy. This study showed adverse associations between seminal phthalate metabolite concentrations and semen quality [163].

Phthalate metabolites were measured in nail samples from Belgium, and the total concentrations ranged between $<12$ and $7980 \mathrm{ng} / \mathrm{g}$. It should be noted, however, that some phthalates, especially DBP, are used in nail polishes and that care should be exercised in interpreting such measurements. MEHP, $\mathrm{MBP}$, and MEP were the major metabolites detected in every nail sample, with a median concentration of 138, 74, and $64 \mathrm{ng} / \mathrm{g}$, respectively [135]. Another study of nail samples from Oslo, Norway, showed the presence of monoesters, such as MMP (geometric mean $89.7 \mathrm{ng} / \mathrm{g}$ ), MEP (104.8 ng/g), and MBP $(89.3 \mathrm{ng} / \mathrm{g})$ [112]. The utility of other biologic matrices, such as blood, breast milk, semen, and nails, for assessing human exposure to phthalates remains largely unknown due to the limited data.

\section{Select Epidemiological Studies Linking Phthalate Exposure and Health Outcomes}

Controlled laboratory animal studies on the toxic effects of phthalates have enabled understanding of biological plausibility and potential mechanisms of actions of this class of chemicals. Thus far, the majority of the laboratory animal exposure/toxicity studies have focused on DEHP and DBP/DiBP, with limited studies examining the toxicities of other phthalates [164-191]. The reproductive and developmental effects of phthalates are among the most studied and well-described toxic endpoints in 
those studies. The toxic endpoints determined in animal studies, following phthalate exposure, include retention of nipples, anogenital distance, pathological changes in testes and male reproductive accessory glands, hypospadias, cryptorchidism, and semen parameters. Phthalates have well-documented anti-androgenic activity in rodent studies that result in reduced circulating testosterone. Several reviews have been published on the toxicity of phthalates [10,14,168-170]. As a class of well-studied endocrine disrupting chemicals, exposure to phthalates has been linked to sex anomalies, endometriosis, altered reproductive development, early puberty and fertility, breast and skin cancer, allergy and asthma, overweight and obesity, insulin resistance, and type II diabetes.

\subsection{Diabetes}

Diabetes is a metabolic disease that results in elevated blood glucose levels. Epidemiological studies in the US $[192,193]$ reported that women with higher urinary concentrations of MBP, MiBP, $\mathrm{MBzP}$, and MCPP and those of DEHP metabolites showed increased risk of diagnosis for diabetes in comparison with those who had lower concentrations of phthalates. Phthalate exposures have been shown to result in insulin resistance [166,194].

\subsection{Overweight and Obesity}

Overweight and obesity can be associated with many chronic diseases, including diabetes. Phthalate exposure was associated with increased body mass and waist circumference [195]. Some phthalate metabolites (MEP, MBP, and MiBP) were associated with obesity in children, whereas MEHP, MECPP, MEHHP, MEOHP, MBzP, and MCNP were associated with obesity in adults. Further, DEHP metabolites were found to be significantly associated with obesity in adult females and older males [196]. Urinary concentration of MBP was associated with fat deposition in boys in China [197].

Several studies have shown a significant association between obesity and phthalate exposure [193,196,198]. MEP, MEHP, MBzP, MEHHP, and MEOHP were associated with obesity in the US population [198]. MBzP, MEHHP, MEOHP, and MEP were associated with increased waist circumference and BMI [193] In contrast, higher concentrations of MEP and DEHP were found in the serum and urine of individuals who were undergoing weight loss [199]. Food intake is the main source of phthalate exposure (for high molecular weight phthalates). Therefore, overweight population with high food intake might have high phthalate exposures.

\subsection{Allergy and Asthma}

Exposure to high molecular weight phthalates are is associated with allergies and asthma $[200,201]$. Studies indicated that children are prone to exposure to DEHP, BzBP, DBP, and DEP and that exposure was associated with allergic rhinitis, atopic dermatitis, and conjunctivitis [202]. DEHP and BzBP and their monoesters are regarded as allergens, and exposure to them has been associated with asthma and wheezing in adults [200,201]. Exposure of DEHP, BzBP, DBP, and DEP during gestation has been associated with allergic responses in infants and toddlers [200]. Urinary MEHP concentrations are correlated with asthma in children [203]. Prenatal exposure to DEHP metabolites and BzBP has been associated with the risk of developing asthma at the age of 7 years and older [204].

\subsection{Reproductive Health}

Urinary MEP and MBP and the metabolites of DEHP and DiNP are associated with anomalies in pubertal development in girls [205]. A significant association between urinary concentrations of MBzP, MEHP, and MEP and increased risk of endometriosis was found in women [206]. Exposure to MEP, $\mathrm{MiBP}$, and MBP pose an increased risk of pregnancy loss in Chinese women.

Poor semen quality was associated with exposure to phthalate metabolites. MBP and MBzP were strongly associated with spermatotoxicity and subfertility in males [32,54]. Significantly higher concentrations of DEHP $(4.66 \mu \mathrm{g} / \mathrm{mL})$ and MEHP $(3.19 \mu \mathrm{g} / \mathrm{mL})$ were found in the urine of 40 Turkish boys with gynecomastia as compared to that of control groups [207]. Several reviews have appeared 
on the reproductive and developmental toxicities of phthalates [208]. Whereas some inconsistencies exist across phthalates for specific health outcomes associated with exposures, moderate to strong evidence of male reproductive effects have been demonstrated in the literature [208]. Because humans are exposed to thousands of harmful chemicals, establishing the link between exposure to a single substance class and adverse health outcomes is fraught with uncertainties.

\section{Conclusions and Perspectives}

Human biomonitoring studies are useful in elucidating exposures and body burdens of phthalates at a population level. Although the sources of exposure to phthalates are well described, several questions about cumulative exposures to phthalates throughout the life span, relative contributions of various sources to cumulative exposures, and mixed exposures that may include phthalates or other chemicals that may elicit common adverse outcomes remain unanswered. Biomonitoring studies clearly demonstrate that human exposures are almost ubiquitous, and, in most cases, children have higher exposures than do adults. The existing studies indicate that the observed associations between phthalate exposure and disease outcomes are exploratory and preliminary, the health effects of phthalate exposure warrant further study. Robust analytical methods exist to measure more than 20 phthalate metabolites in urine, a preferred matrix of choice for biomonitoring studies. Although studies have reported the occurrence of phthalate metabolites in other human specimens, including serum, seminal plasma, and amniotic fluid, the relevance of these matrices in understanding toxic effects needs further investigation. Although biomonitoring studies select major biomarkers/metabolites of phthalates, several other intermediate and transformation products of phthalates appear to exist in human specimens. These intermediates may have more pronounced effects on health. Lack of analytical standards hinders the identification of those intermediate biological transformation products of phthalates. Further, the interaction of phthalate metabolites with other contaminants should be considered in future investigations.

There is a lack of biomonitoring data on phthalate exposures in developing countries in Africa and South America. Studies are needed in those regions with regard to exposures and associated health outcomes in populations. Further, epigenetic effects of phthalate exposures warrant further investigation.

Funding: Research reported in this publication was supported, in part, by the National Institute of Environmental Health Sciences of the National Institutes of Health under Award No. U2CES026542-01. The content is solely the responsibility of the authors and does not necessarily represent the official views of the National Institutes of Health.

Conflicts of Interest: The authors declare no conflict of interest.

\section{References}

1. Latini, G. Monitoring phthalate exposure in humans. Clin. Chim. Acta 2005, 361, 20-29. [CrossRef] [PubMed]

2. Frederiksen, H.; Skakkebaek, N.E.; Andersson, A.M. Metabolism of phthalates in humans. Mol. Nutr. Food Res. 2007, 51, 899-911. [CrossRef] [PubMed]

3. Petersen, J.H.; Breindahl, T. Plasticizers in total diet samples, baby food and infant formulae. Food Addit. Contam. 2000, 17, 133-141. [CrossRef] [PubMed]

4. Wormuth, M.; Scheringer, M.; Vollenweider, M.; Hungerbuhler, K. What are the sources of exposure to eight frequently used phthalic acid esters in Europeans? Risk Anal. 2006, 26, 803-824. [CrossRef] [PubMed]

5. Graham, P.R. Phthalate ester plasticizers-Why and how they are used. Environ. Health Perspect. 1973, 3, 3-12. [PubMed]

6. Mackintosh, C.E.; Maldonado, J.A.; Ikonomou, M.G.; Gobas, F.A.P.C. Sorption of phthalate esters and PCBs in a marine ecosystem. Environ. Sci. Technol. 2006, 40, 3481-3488. [CrossRef]

7. Sirivarasai, J.; Wananukul, W.; Kaojarern, S.; Chanprasertyothin, S.; Thongmung, N.; Ratanachaiwong, W.; Sura, T.; Sritara, P. Association between inflammatory marker, environmental lead exposure and glutathione S-transferase gene. Toxicol. Lett. 2013, 221, 61. [CrossRef] 
8. Net, S.; Sempere, R.; Delmont, A.; Paluselli, A.; Ouddane, B. Occurrence, fate, behavior and ecotoxicological state of phthalates in different environmental matrices. Environ. Sci. Technol. 2015, 49, 4019-4035. [CrossRef]

9. Gimeno, P.; Thomas, S.; Bousquet, C.; Maggio, A.F.; Civade, C.; Brenier, C.; Bonnet, P.A. Identification and quantification of 14 phthalates and 5 non-phthalate plasticizers in PVC medical devices by GC-MS. J. Chromatogr. B 2014, 949-950, 99-108. [CrossRef] [PubMed]

10. Kay, V.R.; Bloom, M.S.; Foster, W.G. Reproductive and developmental effects of phthalate diesters in males. Crit. Rev. Toxicol. 2014, 44, 467-498. [CrossRef]

11. Talsness, C.E.; Andrade, A.J.M.; Kuriyama, S.N.; Taylor, J.A.; vom Saal, F.S. Components of plastic: Experimental studies in animals and relevance for human health. Philos. Trans. R. Soc. Lond. B Biol. Sci. 2009, 364, 2079-2096. [CrossRef] [PubMed]

12. Gray, J.L.E.; Ostby, J.; Furr, J.; Wolf, C.J.; Lambright, C.; Parks, L.; Veeramachaneni, D.N.; Wilson, V.; Price, M.; Hotchkiss, A.; et al. Effects of environmental antiandrogens on reproductive development in experimental animals. Hum. Reprod. Update 2001, 7, 248-264. [CrossRef] [PubMed]

13. Shehata, A.; Mohamed, Z.; El-Haleem, M.; Samak, M. Effects of exposure to plasticizers di-(2-ethylhexyl) phthalate and trioctyltrimellitate on the histological structure of adult male albino rats' liver. J. Clin. Toxicol. 2013, 3, 169-178.

14. Rusyn, I.; Peters, J.M.; Cunningham, M.L. Modes of action and species-specific effects of di-(2-ethylhexyl)phthalate in the liver. Crit. Rev. Toxicol. 2006, 36, 459-479. [CrossRef] [PubMed]

15. Wei, Z.; Song, L.; Wei, J.; Chen, T.; Chen, J.; Lin, Y.; Xia, W.; Xu, B.; Li, X.; Chen, X.; et al. Maternal exposure to di-(2-ethylhexyl)phthalate alters kidney development through the renin-angiotensin system in offspring. Toxicol. Lett. 2012, 212, 212-221. [CrossRef] [PubMed]

16. Crocker, J.F.S.; Safe, S.H.; Acott, P. Effects of chronic phthalate exposure on the kidney. J. Toxicol. Environ. Health 1988, 23, 433-444. [CrossRef]

17. Guo, Y.; Kannan, K. A survey of phthalates and parabens in personal care products from the United States and its implications for human exposure. Environ. Sci. Technol. 2013, 47, 14442-14449. [CrossRef]

18. Guo, Y.; Wang, L.; Kannan, K. Phthalates and parabens in personal care products from China: Concentrations and human exposure. Arch. Environ. Contam. Toxicol. 2014, 66, 113-119. [CrossRef] [PubMed]

19. Specht, I.O.; Toft, G.; Hougaard, K.S.; Lindh, C.H.; Lenters, V.; Jonsson, B.A.G.; Heederik, D.; Giwercman, A.; Bonde, J.P.E. Associations between serum phthalates and biomarkers of reproductive function in 589 adult men. Environ. Int. 2014, 66, 146-156. [CrossRef] [PubMed]

20. Dong, R.H.; Zhou, T.; Zhao, S.Z.; Zhang, H.; Zhang, M.R.; Chen, J.S.; Wang, M.; Wu, M.; Li, S.G.; Chen, B. Food consumption survey of Shanghai adults in 2012 and its associations with phthalate metabolites in urine. Environ. Int. 2017, 101, 80-88. [CrossRef]

21. Silva, M.J.; Samandar, E.; Preau, J.L., Jr.; Reidy, J.A.; Needham, L.L.; Calafat, A.M. Quantification of 22 phthalate metabolites in human urine. J. Chromatogr. B Anal. Technol. Biomed. Life Sci. 2007, 860, 106-112. [CrossRef]

22. Chen, Q.; Yang, H.; Zhou, N.Y.; Sun, L.; Bao, H.Q.; Tan, L.; Chen, H.Q.; Ling, X.; Zhang, G.W.; Huang, L.P.; et al. Phthalate exposure, even below US EPA reference doses, was associated with semen quality and reproductive hormones: Prospective MARHCS study in general population. Environ. Int. 2017, 104, 58-68. [CrossRef] [PubMed]

23. Nassan, F.L.; Coull, B.A.; Skakkebaek, N.E.; Williams, M.A.; Dadd, R.; Minguez-Alarcon, L.; Krawetz, S.A.; Hait, E.J.; Korzenik, J.R.; Moss, A.C.; et al. A crossover-crossback prospective study of dibutyl-phthalate exposure from mesalamine medications and semen quality in men with inflammatory bowel disease. Environ. Int. 2016, 95, 120-130. [CrossRef]

24. Högberg, J.; Hanberg, A.; Berglund, M.; Skerfving, S.; Remberger, M.; Calafat, A.M.; Filipsson, A.F.; Jansson, B.; Johansson, N.; Appelgren, M.; et al. Phthalate diesters and their metabolites in human breast milk, blood or serum, and urine as biomarkers of exposure in vulnerable populations. Environ. Health Perspect. 2008, 116, 334-339. [CrossRef] [PubMed]

25. Main, K.M.; Mortensen, G.K.; Kaleva, M.M.; Boisen, K.A.; Damgaard, I.N.; Chellakooty, M.; Schmidt, I.M.; Suomi, A.-M.; Virtanen, H.E.; Petersen, J.H.; et al. Human breast milk contamination with phthalates and alterations of endogenous reproductive hormones in infants three months of age. Environ. Health Perspect. 2006, 114, 270-276. [CrossRef] 
26. Asimakopoulos, A.G.; Xue, J.; De Carvalho, B.P.; Iyer, A.; Abualnaja, K.O.; Yaghmoor, S.S.; Kumosani, T.A.; Kannan, K. Urinary biomarkers of exposure to 57 xenobiotics and its association with oxidative stress in a population in Jeddah, Saudi Arabia. Environ. Res. 2016, 150, 573-581. [CrossRef] [PubMed]

27. Ferguson, K.K.; McElrath, T.F.; Chen, Y.-H.; Mukherjee, B.; Meeker, J.D. Urinary phthalate metabolites and biomarkers of oxidative stress in pregnant women: A repeated measures analysis. Environ. Health Perspect. 2015, 123, 210-216. [CrossRef]

28. Colón, I.; Caro, D.; Bourdony, C.J.; Rosario, O. Identification of phthalate esters in the serum of young Puerto Rican girls with premature breast development. Environ. Health Perspect. 2000, 108, 895-900. [PubMed]

29. Buck Louis, G.M.; Gray, L.E.; Marcus, M.; Ojeda, S.R.; Pescovitz, O.H.; Witchel, S.F.; Sippell, W.; Abbott, D.H.; Soto, A.; Tyl, R.W.; et al. Environmental factors and puberty timing: Expert panel research needs. Pediatrics 2008, 121, 192-207. [CrossRef] [PubMed]

30. Cobellis, L.; Latini, G.; Felice, C.D.; Razzi, S.; Paris, I.; Ruggieri, F.; Mazzeo, P.; Petraglia, F. High plasma concentrations of di-(2-ethylhexyl)-phthalate in women with endometriosis. Hum. Reprod. 2003, 18, 1512-1515. [CrossRef] [PubMed]

31. Reddy, B.S.; Rozati, R.; Reddy, B.V.R.; Raman, N. General gynaecology: Association of phthalate esters with endometriosis in Indian women. Int. J. Gynaecol. Obstet. 2006, 113, 515-520. [CrossRef] [PubMed]

32. Duty, S.M.; Silva, M.J.; Barr, D.B.; Brock, J.W.; Ryan, L.; Chen, Z.; Herrick, R.F.; Christiani, D.C.; Hauser, R. Phthalate exposure and human semen parameters. Epidemiology 2003, 14, 269-277. [CrossRef]

33. Joensen Ulla, N.; Frederiksen, H.; Jensen Martin, B.; Lauritsen Mette, P.; Olesen Inge, A.; Lassen Tina, H.; Andersson, A.M.; Jørgensen, N. Phthalate excretion pattern and testicular function: A study of 881 healthy danish men. Environ. Health Perspect. 2012, 120, 1397-1403. [CrossRef] [PubMed]

34. Yaghjyan, L.; Sites, S.; Ruan, Y.; Chang, S.H. Associations of urinary phthalates with body mass index, waist circumference and serum lipids among females: National Health and Nutrition Examination Survey 1999-2004. Int. J. Obstet. 2015, 36, 994-1000. [CrossRef] [PubMed]

35. López-Carrillo, L.; Hernández-Ramírez, R.U.; Calafat, A.M.; Torres-Sánchez, L.; Galván-Portillo, M.; Needham, L.L.; Ruiz-Ramos, R.; Cebrián, M.E. Exposure to phthalates and breast cancer risk in Northern Mexico. Environ. Health Perspect. 2010, 118, 539-544. [CrossRef] [PubMed]

36. Monographs on the Evaluation of Carcinogenic Risks to Humans. Available online: https://monographs.iarc. fr/wp-content/uploads/2018/06/mono77.pdf (accessed on 5 April 2019).

37. Le Moal, J.; Sharpe, R.M.; Jфrgensen, N.; Levine, H.; Jurewicz, J.; Mendiola, J.; Swan, S.H.; Virtanen, H.; Christin-Maître, S.; Cordier, S.; et al. Toward a multi-country monitoring system of reproductive health in the context of endocrine disrupting chemical exposure. Eur. J. Public Health. 2016, 26, 76-83. [CrossRef]

38. Sharpe, R.M.; Skakkebaek, N.E. Testicular dysgenesis syndrome: Mechanistic insights and potential new downstream effects. Fertil. Steril. 2008, 89, 33-38. [CrossRef] [PubMed]

39. Kuo, C.C.; Moon, K.; Thayer, K.A.; Navas-Acien, A. Environmental chemicals and type 2 diabetes: An updated systematic review of the epidemiologic evidence. Curr. Diabetes Rep. 2013, 13, 831-849. [CrossRef]

40. Swan, S.H. Environmental phthalate exposure in relation to reproductive outcomes and other health endpoints in humans. Environ. Res. 2008, 108, 177-184. [CrossRef]

41. Goen, T.; Dobler, L.; Koschorreck, J.; Muller, J.; Wiesmuller, G.A.; Drexler, H.; Kolossa-Gehring, M. Trends of the internal phthalate exposure of young adults in Germany-Follow-up of a retrospective human biomonitoring study. Int. J. Hyg. Environ. Health 2011, 215, 36-45. [CrossRef] [PubMed]

42. Tranfo, G.; Caporossi, L.; Pigini, D.; Capanna, S.; Papaleo, B.; Paci, E. Temporal trends of urinary phthalate concentrations in two populations: Effects of REACH authorization after five years. Int. J. Environ. Res. Public Health 2018, 15, 1950. [CrossRef]

43. North, M.L.; Takaro, T.K.; Diamond, M.L.; Ellis, A.K. Effects of phthalates on the development and expression of allergic disease and asthma. Ann. Allergy Asthma Immunol. 2014, 112, 496-502. [CrossRef] [PubMed]

44. Wittassek, M.; Koch, H.M.; Angerer, J.; Bruning, T. Assessing exposure to phthalates-The human biomonitoring approach. Mol. Nutr. Food Res. 2011, 55, 7-31. [CrossRef] [PubMed]

45. Sapozhnikova, Y.; Hoh, E. Suspect screening of chemicals in food packaging film by comprehensive two-dimensional gas chromatography coupled to time-of-flight mass spectrometry. LCGC N. Am. 2019, 37, $52-60$. 
46. Tran, T.M.; Kannan, K. Occurrence of phthalate diesters in particulate and vapor phases in indoor air and implications for human exposure in Albany, New York, USA. Arch. Environ. Contam. Toxicol. 2015, 68, 489-499. [CrossRef]

47. Guo, Y.; Kannan, K. Comparative assessment of human exposure to phthalate esters from house dust in China and the United States. Environ. Sci. Technol. 2011, 45, 3788-3794. [CrossRef] [PubMed]

48. Moreta, C.; Tena, M.T.; Kannan, K. Analytical method for the determination and a survey of parabens and its derivatives in pharmaceuticals. Environ. Res. 2015, 142, 452-460. [CrossRef] [PubMed]

49. Hauser, R.; Duty, S.; Godfrey-Bailey, L.; Calafat, A.M. Medications as a source of human exposure to phthalates. Environ. Health Perspect. 2004, 112, 751-753. [CrossRef] [PubMed]

50. U.S. FDA. Safety Assessment of Di(2-ethylhexyl)phthalate (DEHP) Released from PVC Medical Devices, Rockville, MD 20852. Available online: https://noharm-global.org/documents/safety-assessment-dehpreleased-pvc-medical-devices (accessed on 5 April 2019).

51. Guo, Y.; Wu, Q.; Kannan, K. Phthalate metabolites in urine from China, and implications for human exposures. Environ. Int. 2011, 37, 893-898. [CrossRef] [PubMed]

52. Lind, P.M.; Roos, V.; Ronn, M.; Johansson, L.; Ahlstrom, H.; Kullberg, J.; Lind, L. Serum concentrations of phthalate metabolites are related to abdominal fat distribution two years later in elderly women. Environ. Health 2012, 11, 21-29. [CrossRef] [PubMed]

53. Kato, K.; Silva, M.J.; Brock, J.W.; Reidy, J.A.; Malek, N.A.; Hodge, C.C.; Nakazawa, H.; Needham, L.L.; Barr, D.B. Quantitative Detection of Nine Phthalate Metabolites in Human Serum Using Reversed-Phase High-Performance Liquid Chromatography-Electrospray Ionization-Tandem Mass Spectrometry. J. Anal. Toxicol. 2003, 27, 284-289. [CrossRef]

54. Hauser, R.; Meeker, J.D.; Duty, S.; Silva, M.J.; Calafat, A.M. Altered semen quality in relation to urinary concentrations of phthalate monoester and oxidative metabolites. Epidemiology 2006, 17, 682-691. [CrossRef]

55. Zhu, J.P.; Phillips, S.P.; Feng, Y.L.; Yang, X.F. Phthalate esters in human milk: Concentration variations over a 6-month postpartum time. Environ. Sci. Technol. 2006, 40, 5276-5281. [CrossRef] [PubMed]

56. Damgaard, I.N.; Skakkebæk, N.E.; Toppari, J.; Virtanen, H.E.; Shen, H.; Schramm, K.W.; Petersen, J.H.; Jensen, T.K.; Main, K.M.; the Nordic Cryptorchidism Study, G. Persistent pesticides in human breast milk and cryptorchidism. Environ. Health Perspect. 2006, 114, 1133-1138. [CrossRef] [PubMed]

57. Silva, M.J.; Reidy, J.A.; Samandar, E.; Herbert, A.R.; Needham, L.L.; Calafat, A.M. Detection of phthalate metabolites in human saliva. Arch. Toxicol. 2005, 79, 647-652. [CrossRef]

58. Fennell, T.R.; Krol, W.L.; Sumner, S.C.J.; Snyder, R.W. Pharmacokinetics of dibutylphthalate in pregnant rats. Toxicol. Sci. 2004, 82, 407-418. [CrossRef]

59. Silva, M.J.; Reidy, J.A.; Herbert, A.R.; Preau, J.L.; Needham, L.L.; Calafat, A.M. Detection of phthalate metabolites in human amniotic fluid. Bull. Environ. Contam. Toxicol. 2004, 72, 1226-1231. [CrossRef] [PubMed]

60. Choi, J.; Knudsen, L.E.; Mizrak, S.; Joas, A. Identification of exposure to environmental chemicals in children and older adults using human biomonitoring data sorted by age: Results from a literature review. Int. J. Hyg. Environ. Health 2017, 220, 282-298. [CrossRef]

61. Heffernan, A.L.; Thompson, K.; Eaglesham, G.; Vijayasarathy, S.; Mueller, J.F.; Sly, P.D.; Gomez, M.J. Rapid, automated online SPE-LC-QTRAP-MS/MS method for the simultaneous analysis of 14 phthalate metabolites and 5 bisphenol analogues in human urine. Talanta 2016, 151, 224-233. [CrossRef]

62. Hartmann, C.; Uhl, M.; Weiss, S.; Koch, H.M.; Scharf, S.; Konig, J. Human biomonitoring of phthalate exposure in Austrian children and adults and cumulative risk assessment. Int. J. Hyg. Environ. Health 2015, 218, 489-499. [CrossRef]

63. Dewalque, L.; Charlier, C.; Pirard, C. Estimated daily intake and cumulative risk assessment of phthalate diesters in a Belgian general population. Toxicol. Lett. 2014, 231, 161-168. [CrossRef]

64. Geens, T.; Bruckers, L.; Covaci, A.; Schoeters, G.; Fierens, T.; Sioen, I.; Vanermen, G.; Baeyens, W.; Morrens, B.; Loots, I.; et al. Determinants of bisphenol A and phthalate metabolites in urine of Flemish adolescents. Environ. Res. 2014, 134, 110-117. [CrossRef]

65. Dewalque, L.; Pirard, C.; Charlier, C. Measurement of urinary biomarkers of parabens, benzophenone-3, and phthalates in a Belgian population. Biomed. Res. Int. 2014, 2014, 649314-649327. [CrossRef] 
66. Dewalque, L.; Pirard, C.; Dubois, N.; Charlier, C. Simultaneous determination of some phthalate metabolites, parabens and benzophenone-3 in urine by ultra high pressure liquid chromatography tandem mass spectrometry. J. Chromatogr. B Anal. Technol. Biomed. Life Sci. 2014, 949-950, 37-47. [CrossRef]

67. Rocha, B.A.; Asimakopoulos, A.G.; Barbosa, F., Jr.; Kannan, K. Urinary concentrations of 25 phthalate metabolites in Brazilian children and their association with oxidative DNA damage. Sci. Total Environ. 2017, 586, 152-162. [CrossRef]

68. Saravanabhavan, G.; Guay, M.; Langlois, E.; Giroux, S.; Murray, J.; Haines, D. Biomonitoring of phthalate metabolites in the Canadian population through the Canadian Health Measures Survey (2007-2009). Int. J. Hyg. Environ. Health 2013, 216, 652-661. [CrossRef]

69. Arbuckle, T.E.; Davis, K.; Marro, L.; Fisher, M.; Legrand, M.; LeBlanc, A.; Gaudreau, E.; Foster, W.G.; Choeurng, V.; Fraser, W.D.; et al. Phthalate and bisphenol A exposure among pregnant women in Canada-Results from the MIREC study. Environ. Int. 2014, 68, 55-65. [CrossRef]

70. Arbuckle, T.E.; Fisher, M.; MacPherson, S.; Lang, C.; Provencher, G.; LeBlanc, A.; Hauser, R.; Feeley, M.; Ayotte, P.; Neisa, A.; et al. Maternal and early life exposure to phthalates: The plastics and personal-care products use in pregnancy (P4) study. Sci. Total Environ. 2016, 551-552, 344-356. [CrossRef]

71. Gao, C.-J.; Liu, L.-Y.; Ma, W.-L.; Ren, N.-Q.; Guo, Y.; Zhu, N.-Z.; Jiang, L.; Li, Y.-F.; Kannan, K. Phthalate metabolites in urine of Chinese young adults: Concentration, profile, exposure and cumulative risk assessment. Sci. Total Environ. 2016, 543, 19-27. [CrossRef]

72. Guo, Y.; Alomirah, H.; Cho, H.-S.; Minh, T.B.; Mohd, M.A.; Nakata, H.; Kannan, K. Occurrence of phthalate metabolites in human urine from several Asian countries. Environ. Sci. Technol. 2011, 45, 3138-3144. [CrossRef]

73. Shen, Q.; Shi, H.J.; Zhang, Y.H.; Cao, Y. Dietary intake and phthalates body burden in boys and girls. Arch. Public Health 2015, 73, 5-10. [CrossRef]

74. Zhang, J.; Liu, L.; Wang, X.; Huang, Q.; Tian, M.; Shen, H. Low-level environmental phthalate exposure associates with urine metabolome alteration in a Chinese male cohort. Environ. Sci. Technol. 2016, 50, 5953-5960. [CrossRef]

75. Gong, M.; Weschler, C.J.; Liu, L.; Shen, H.; Huang, L.; Sundell, J.; Zhang, Y. Phthalate metabolites in urine samples from Beijing children and correlations with phthalate levels in their handwipes. Indoor Air 2015, 25, 572-581. [CrossRef]

76. Černá, M.; Malý, M.; Rudnai, P.; Középesy, S.; Náray, M.; Halzlová, K.; Jajcaj, M.; Grafnetterová, A.; Krsková, A.; Antošová, D.; et al. Case study: Possible differences in phthalates exposure among the Czech, Hungarian, and Slovak populations identified based on the DEMOCOPHES pilot study results. Environ. Res. 2015, 141, 118-124. [CrossRef] [PubMed]

77. Frederiksen, H.; Jorgensen, N.; Andersson, A.M. Correlations between phthalate metabolites in urine, serum, and seminal plasma from young Danish men determined by isotope dilution liquid chromatography tandem mass spectrometry. J. Anal. Toxicol. 2010, 34, 400-410. [CrossRef] [PubMed]

78. Frederiksen, H.; Nielsen, J.K.S.; Mørck, T.A.; Hansen, P.W.; Jensen, J.F.; Nielsen, O.; Andersson, A.-M.; Knudsen, L.E. Urinary excretion of phthalate metabolites, phenols and parabens in rural and urban Danish mother-child pairs. Int. J. Hyg. Environ. Health 2013, 216, 772-783. [CrossRef]

79. Frederiksen, H.; Aksglaede, L.; Sorensen, K.; Skakkebaek, N.E.; Juul, A.; Andersson, A.-M. Urinary excretion of phthalate metabolites in 129 healthy Danish children and adolescents: Estimation of daily phthalate intake. Environ. Res. 2011, 111, 656-663. [CrossRef] [PubMed]

80. Langer, S.; Beko, G.; Weschler, C.J.; Brive, L.M.; Toftum, J.; Callesen, M.; Clausen, G. Phthalate metabolites in urine samples from Danish children and correlations with phthalates in dust samples from their homes and daycare centers. Int. J. Hyg. Environ. Health 2014, 217, 78-87. [CrossRef] [PubMed]

81. Schwedler, G.; Seiwert, M.; Fiddicke, U.; Issleb, S.; Holzer, J.; Nendza, J.; Wilhelm, M.; Wittsiepe, J.; Koch, H.M.; Schindler, B.K.; et al. Human biomonitoring pilot study DEMOCOPHES in Germany: Contribution to a harmonized European approach. Int. J. Hyg. Environ. Health 2017, 220, 686-696. [CrossRef]

82. Haug, L.S.; Sakhi, A.K.; Cequier, E.; Casas, M.; Maitre, L.; Basagana, X.; Andrusaityte, S.; Chalkiadaki, G.; Chatzi, L.; Coen, M.; et al. In-utero and childhood chemical exposome in six European mother-child cohorts. Environ. Int. 2018, 121, 751-763. [CrossRef] 
83. Zeman, F.A.; Boudet, C.; Tack, K.; Floch Barneaud, A.; Brochot, C.; Pery, A.R.; Oleko, A.; Vandentorren, S. Exposure assessment of phthalates in French pregnant women: Results of the ELFE pilot study. Int. J. Hyg. Environ. Health 2013, 216, 271-279. [CrossRef]

84. Wittassek, M.; Wiesmuller, G.A.; Koch, H.M.; Eckard, R.; Dobler, L.; Muller, J.; Angerer, J.; Schluter, C. Internal phthalate exposure over the last two decades-A retrospective human biomonitoring study. Int. J. Hyg. Environ. Health 2007, 210, 319-333. [CrossRef]

85. Becker, K.; Seiwert, M.; Angerer, J.; Heger, W.; Koch, H.M.; Nagorka, R.; Roßkamp, E.; Schlüter, C.; Seifert, B.; Ullrich, D. DEHP metabolites in urine of children and DEHP in house dust. Int. J. Hyg. Environ. Health 2004, 207, 409-417. [CrossRef]

86. Koch, H.M.; Drexler, H.; Angerer, J. An estimation of the daily intake of di(2-ethylhexyl)phthalate (DEHP) and other phthalates in the general population. Int. J. Hyg. Environ. Health 2003, 206, 77-83. [CrossRef]

87. Fromme, H.; Bolte, G.; Koch, H.M.; Angerer, J.; Boehmer, S.; Drexler, H.; Mayer, R.; Liebl, B. Occurrence and daily variation of phthalate metabolites in the urine of an adult population. Int. J. Hyg. Environ. Health 2007, 210, 21-33. [CrossRef]

88. Koch, H.M.; Ruther, M.; Schutze, A.; Conrad, A.; Palmke, C.; Apel, P.; Bruning, T.; Kolossa-Gehring, M. Phthalate metabolites in 24-h urine samples of the German Environmental Specimen Bank (ESB) from 1988 to 2015 and a comparison with US NHANES data from 1999 to 2012. Int. J. Hyg. Environ. Health 2017, 220, 130-141. [CrossRef]

89. Koch, H.M.; Wittassek, M.; Bruning, T.; Angerer, J.; Heudorf, U. Exposure to phthalates in 5-6 years old primary school starters in Germany-A human biomonitoring study and a cumulative risk assessment. Int. J. Hyg. Environ. Health 2011, 214, 188-195. [CrossRef]

90. Kasper-Sonnenberg, M.; Koch, H.M.; Wittsiepe, J.; Bruning, T.; Wilhelm, M. Phthalate metabolites and bisphenol A in urines from German school-aged children: Results of the Duisburg birth cohort and Bochum cohort studies. Int. J. Hyg. Environ. Health 2014, 217, 830-838. [CrossRef]

91. Becker, K.; Goen, T.; Seiwert, M.; Conrad, A.; Pick-Fuss, H.; Muller, J.; Wittassek, M.; Schulz, C.; Kolossa-Gehring, M. GerES IV: Phthalate metabolites and bisphenol A in urine of German children. Int. J. Hyg. Environ. Health 2009, 212, 685-692. [CrossRef]

92. Volkel, W.; Kiranoglu, M.; Schuster, R.; Fromme, H. Hbmnet Phthalate intake by infants calculated from biomonitoring data. Toxicol. Lett. 2014, 225, 222-229. [CrossRef]

93. Kasper-Sonnenberg, M.; Koch, H.M.; Wittsiepe, J.; Wilhelm, M. Levels of phthalate metabolites in urine among mother-child-pairs-Results from the Duisburg birth cohort study, Germany. Int. J. Hyg. Environ. Health 2012, 215, 373-382. [CrossRef]

94. Myridakis, A.; Fthenou, E.; Balaska, E.; Vakinti, M.; Kogevinas, M.; Stephanou, E.G. Phthalate esters, parabens and bisphenol-A exposure among mothers and their children in Greece (Rhea cohort). Environ. Int. 2015, 83, 1-10. [CrossRef] [PubMed]

95. Jeddi, M.Z.; Gorji, M.E.; Rietjens, I.M.C.M.; Louisse, J.; Bruinen de Bruin, Y.; Liska, R. Biomonitoring and subsequent risk assessment of combined exposure to phthalates in Iranian children and adolescents. Int. J. Environ. Res. Public Health 2018, 15, 2336. [CrossRef]

96. Cullen, E.; Evans, D.; Griffin, C.; Burke, P.; Mannion, R.; Burns, D.; Flanagan, A.; Kellegher, A.; Schoeters, G.; Govarts, E.; et al. Urinary phthalate concentrations in mothers and their children in Ireland: Results of the DEMOCOPHES human biomonitoring study. Int. J. Environ. Res. Public Health 2017, 14, 1456. [CrossRef] [PubMed]

97. Berman, T.; Goldsmith, R.; Goen, T.; Spungen, J.; Novack, L.; Levine, H.; Amitai, Y.; Shohat, T.; Grotto, I. Urinary concentrations of environmental contaminants and phytoestrogens in adults in Israel. Environ. Int. 2013, 59, 478-484. [CrossRef] [PubMed]

98. Tranfo, G.; Papaleo, B.; Caporossi, L.; Capanna, S.; De Rosa, M.; Pigini, D.; Corsetti, F.; Paci, E. Urinary metabolite concentrations of phthalate metabolites in Central Italy healthy volunteers determined by a validated HPLC/MS/MS analytical method. Int. J. Hyg. Environ. Health 2013, 216, 481-485. [CrossRef]

99. Itoh, H.; Iwasaki, M.; Hanaoka, T.; Sasaki, H.; Tanaka, T.; Tsugane, S. Urinary phthalate monoesters and endometriosis in infertile Japanese women. Sci. Total Environ. 2009, 408, 37-42. [CrossRef] [PubMed]

100. Itoh, H.; Yoshida, K.; Masunaga, S. Quantitative identification of unknown exposure pathways of phthalates based on measuring their metabolites in human urine. Environ. Sci. Technol. 2007, 41, 4542-4547. [CrossRef] 
101. Suzuki, Y.; Yoshinaga, J.; Mizumoto, Y.; Serizawa, S.; Shiraishi, H. Foetal exposure to phthalate esters and anogenital distance in male newborns. Int. J. Androl. 2012, 35, 236-244. [CrossRef]

102. Kim, S.; Kang, S.; Lee, G.; Lee, S.; Jo, A.; Kwak, K.; Kim, D.; Koh, D.; Kho, Y.L.; Kim, S.; et al. Urinary phthalate metabolites among elementary school children of Korea: Sources, risks, and their association with oxidative stress marker. Sci. Total Environ. 2014, 472, 49-55. [CrossRef]

103. Ji, K.; Lim Kho, Y.; Park, Y.; Choi, K. Influence of a five-day vegetarian diet on urinary levels of antibiotics and phthalate metabolites: A pilot study with “Temple Stay" participants. Environ. Res. 2010, 110, 375-382. [CrossRef]

104. Jo, A.; Kim, H.; Chung, H.; Chang, N. Associations between dietary intake and urinary bisphenol A and phthalates levels in Korean women of reproductive age. Int. J. Environ. Res. Public Health 2016, 13, 680. [CrossRef] [PubMed]

105. Kim, J.H.; Lee, S.; Shin, M.Y.; Kim, K.N.; Hong, Y.C. Risk assessment for phthalate exposures in the elderly: A repeated biomonitoring study. Sci. Total Environ. 2018, 618, 690-696. [CrossRef]

106. Choi, W.; Kim, S.; Baek, Y.W.; Choi, K.; Lee, K.; Kim, S.; Yu, S.D.; Choi, K. Exposure to environmental chemicals among Korean adults-updates from the second Korean National Environmental Health Survey (2012-2014). Int. J. Hyg. Environ. Health 2017, 220, 29-35. [CrossRef] [PubMed]

107. Park, C.; Choi, W.; Hwang, M.; Lee, Y.; Kim, S.; Yu, S.; Lee, I.; Paek, D.; Choi, K. Associations between urinary phthalate metabolites and bisphenol A levels, and serum thyroid hormones among the Korean adult population-Korean National Environmental Health Survey (KoNEHS) 2012-2014. Sci. Total Environ. 2017, 584-585, 950-957. [CrossRef]

108. Kim, S.; Lee, J.; Park, J.; Kim, H.J.; Cho, G.J.; Kim, G.H.; Eun, S.H.; Lee, J.J.; Choi, G.; Suh, E.; et al. Urinary phthalate metabolites over the first 15 months of life and risk assessment-CHECK cohort study. Sci. Total Environ. 2017, 607-608, 881-887. [CrossRef] [PubMed]

109. Song, N.R.; On, J.W.; Lee, J.; Park, J.D.; Kwon, H.J.; Yoon, H.J.; Pyo, H. Biomonitoring of urinary di(2-ethylhexyl) phthalate metabolites of mother and child pairs in South Korea. Environ. Int. 2013, 54, 65-73. [CrossRef] [PubMed]

110. Ye, X.; Pierik, F.H.; Hauser, R.; Duty, S.; Angerer, J.; Park, M.M.; Burdorf, A.; Hofman, A.; Jaddoe, V.W.; Mackenbach, J.P.; et al. Urinary metabolite concentrations of organophosphorous pesticides, bisphenol A, and phthalates among pregnant women in Rotterdam, the Netherlands: The Generation R study. Environ. Res. 2008, 108, 260-267. [CrossRef] [PubMed]

111. Ye, X.; Pierik, F.H.; Angerer, J.; Meltzer, H.M.; Jaddoe, V.W.V.; Tiemeier, H.; Hoppin, J.A.; Longnecker, M.P. Levels of metabolites of organophosphate pesticides, phthalates, and bisphenol A in pooled urine specimens from pregnant women participating in the Norwegian Mother and Child Cohort Study (MoBa). Int. J. Hyg. Environ. Health 2009, 212, 481-491. [CrossRef]

112. Giovanoulis, G.; Alves, A.; Papadopoulou, E.; Cousins, A.P.; Schutze, A.; Koch, H.M.; Haug, L.S.; Covaci, A.; Magner, J.; Voorspoels, S. Evaluation of exposure to phthalate esters and DINCH in urine and nails from a Norwegian study population. Environ. Res. 2016, 151, 80-90. [CrossRef] [PubMed]

113. Sabaredzovic, A.; Sakhi, A.K.; Brantsaeter, A.L.; Thomsen, C. Determination of 12 urinary phthalate metabolites in Norwegian pregnant women by core-shell high performance liquid chromatography with on-line solid-phase extraction, column switching and tandem mass spectrometry. J. Chromatogr. B Anal. Technol. Biomed. Life Sci. 2015, 1002, 343-352. [CrossRef]

114. Correia-Sa, L.; Kasper-Sonnenberg, M.; Palmke, C.; Schutze, A.; Norberto, S.; Calhau, C.; Domingues, V.F.; Koch, H.M. Obesity or diet? Levels and determinants of phthalate body burden-A case study on Portuguese children. Int. J. Hyg. Environ. Health 2018, 221, 519-530. [CrossRef] [PubMed]

115. Petrovicova, I.; Kolena, B.; Sidlovska, M.; Pilka, T.; Wimmerova, S.; Trnovec, T. Occupational exposure to phthalates in relation to gender, consumer practices and body composition. Environ. Sci. Pollut. Res. Int. 2016, 23, 24125-24134. [CrossRef] [PubMed]

116. Kolena, B.; Petrovicova, I.; Sidlovska, M.; Pilka, T.; Neuschlova, M.; Valentova, I.; Rybansky, L.; Trnovec, T. Occupational phthalate exposure and health outcomes among hairdressing apprentices. Hum. Exp. Toxicol. 2017, 36, 1100-1112. [CrossRef]

117. Pilka, T.; Petrovicova, I.; Kolena, B.; Zatko, T.; Trnovec, T. Relationship between variation of seasonal temperature and extent of occupational exposure to phthalates. Environ. Sci. Pollut. Res. Int. 2015, 22, 434-440. [CrossRef] 
118. Valvi, D.; Monfort, N.; Ventura, R.; Casas, M.; Casas, L.; Sunyer, J.; Vrijheid, M. Variability and predictors of urinary phthalate metabolites in Spanish pregnant women. Int. J. Hyg. Environ. Health 2015, 218, 220-231. [CrossRef]

119. Cutanda, F.; Koch, H.M.; Esteban, M.; Sanchez, J.; Angerer, J.; Castano, A. Urinary levels of eight phthalate metabolites and bisphenol A in mother-child pairs from two Spanish locations. Int. J. Hyg. Environ. Health 2015, 218, 47-57. [CrossRef]

120. Axelsson, J.; Rylander, L.; Rignell-Hydbom, A.; Jönsson, B.A.G.; Lindh, C.H.; Giwercman, A. Phthalate exposure and reproductive parameters in young men from the general Swedish population. Environ. Int. 2015, 85, 54-60. [CrossRef]

121. Chen, M.L.; Chen, J.S.; Tang, C.L.; Mao, I.F. The internal exposure of Taiwanese to phthalate-An evidence of intensive use of plastic materials. Environ. Int. 2008, 34, 79-85. [CrossRef]

122. Wirth, J.J.; Rossano, M.G.; Potter, R.; Puscheck, E.; Daly, D.C.; Paneth, N.; Krawetz, S.A.; Protas, B.M.; Diamond, M.P. A pilot study associating urinary concentrations of phthalate metabolites and semen quality. Syst. Biol. Reprod. Med. 2008, 54, 143-154. [CrossRef]

123. Teitelbaum, S.L.; Britton, J.A.; Calafat, A.M.; Ye, X.; Silva, M.J.; Reidy, J.A.; Galvez, M.P.; Brenner, B.L.; Wolff, M.S. Temporal variability in urinary concentrations of phthalate metabolites, phytoestrogens and phenols among minority children in the United States. Environ. Res. 2008, 106, 257-269. [CrossRef] [PubMed]

124. Ferguson, K.K.; Loch-Caruso, R.; Meeker, J.D. Urinary phthalate metabolites in relation to biomarkers of inflammation and oxidative stress: NHANES 1999-2006. Environ. Res. 2011, 111, 718-726. [CrossRef]

125. Brock, J.W.; Caudill, S.P.; Silva, M.J.; Needham, L.L.; Hilborn, E.D. Phthalate monoesters levels in the urine of young children. Bull. Environ. Contam. Toxicol. 2002, 68, 309-314. [CrossRef] [PubMed]

126. Just, A.C.; Adibi, J.J.; Rundle, A.G.; Calafat, A.M.; Camann, D.E.; Hauser, R.; Silva, M.J.; Whyatt, R.M. Urinary and air phthalate concentrations and self-reported use of personal care products among minority pregnant women in New York city. J. Expo. Sci. Environ. Epidemiol. 2010, 20, 625-633. [CrossRef] [PubMed]

127. Polinski, K.J.; Dabelea, D.; Hamman, R.F.; Adgate, J.L.; Calafat, A.M.; Ye, X.; Starling, A.P. Distribution and predictors of urinary concentrations of phthalate metabolites and phenols among pregnant women in the Healthy Start Study. Environ. Res. 2018, 162, 308-317. [CrossRef]

128. Wenzel, A.G.; Brock, J.W.; Cruze, L.; Newman, R.B.; Unal, E.R.; Wolf, B.J.; Somerville, S.E.; Kucklick, J.R. Prevalence and predictors of phthalate exposure in pregnant women in Charleston, SC. Chemosphere 2018, 193, 394-402. [CrossRef]

129. Calafat, A.M.; McKee, R.H. Integrating biomonitoring exposure data into the risk assessment process: Phthalates [diethyl phthalate and di(2-ethylhexyl) phthalate] as a case study. Environ. Health Perspect. 2006, 114, 1783-1789. [CrossRef] [PubMed]

130. Colacino Justin, A.; Harris, T.R.; Schecter, A. Dietary intake Is associated with phthalate body burden in a nationally representative sample. Environ. Health Perspect. 2010, 118, 998-1003. [CrossRef]

131. Hines, E.P.; Calafat, A.M.; Silva, M.J.; Mendola, P.; Fenton, S.E. Concentrations of phthalate metabolites in milk, urine, saliva, and Serum of lactating North Carolina women. Environ. Health Perspect. 2009, 117, 86-92. [CrossRef]

132. Buckley, J.P.; Palmieri, R.T.; Matuszewski, J.M.; Herring, A.H.; Baird, D.D.; Hartmann, K.E.; Hoppin, J.A. Consumer product exposures associated with urinary phthalate levels in pregnant women. J. Expo. Sci. Environ. Epidemiol. 2012, 22, 468-475. [CrossRef]

133. Duty, S.M.; Ackerman, R.M.; Calafat, A.M.; Hauser, R. Personal care product use predicts urinary concentrations of some phthalate monoesters. Environ. Health Perspect. 2005, 113, 1530-1535. [CrossRef]

134. Schlumpf, M.; Kypke, K.; Wittassek, M.; Angerer, J.; Mascher, H.; Mascher, D.; Vökt, C.; Birchler, M.; Lichtensteiger, W. Exposure patterns of UV filters, fragrances, parabens, phthalates, organochlor pesticides, PBDEs, and PCBs in human milk: Correlation of UV filters with use of cosmetics. Chemosphere 2010, 81, 1171-1183. [CrossRef] [PubMed]

135. Alves, A.; Vanermen, G.; Covaci, A.; Voorspoels, S. Ultrasound assisted extraction combined with dispersive liquid-liquid microextraction (US-DLLME) — A fast new approach to measure phthalate metabolites in nails. Anal. Bioanal. Chem. 2016, 408, 6169-6180. [CrossRef] [PubMed]

136. Reddy, B.S.; Rozati, R.; Reddy, S.; Kodampur, S.; Reddy, P.; Reddy, R. High plasma concentrations of polychlorinated biphenyls and phthalate esters in women with endometriosis: A prospective case control study. Fertil. Steril. 2006, 85, 775-779. [CrossRef] [PubMed] 
137. Specht, I.O.; Bonde, J.P.; Toft, G.; Lindh, C.H.; Jonsson, B.A.G.; Jorgensen, K.T. Serum phthalate levels and time to pregnancy in couples from Greenland, Poland and Ukraine. PLoS ONE 2015, 10, 1371-1385. [CrossRef] [PubMed]

138. Calafat, A.M.; Slakman, A.R.; Silva, M.J.; Herbert, A.R.; Needham, L.L. Automated solid phase extraction and quantitative analysis of human milk for 13 phthalate metabolites. J. Chromatogr. B Anal. Technol. Biomed. Life Sci. 2004, 805, 49-56. [CrossRef] [PubMed]

139. Silva, M.J.; Malek, N.A.; Hodge, C.C.; Reidy, J.A.; Kato, K.; Barr, D.B.; Needham, L.L.; Brock, J.W. Improved quantitative detection of 11 urinary phthalate metabolites in humans using liquid chromatography-atmospheric pressure chemical ionization tandem mass spectrometry. J. Chromatogr. B 2003, 789, 393-404. [CrossRef]

140. Calafat, A.M.; Wong, L.Y.; Silva, M.J.; Samandar, E.; Preau, J.L., Jr.; Jia, L.T.; Needham, L.L. Selecting adequate exposure biomarkers of diisononyl and diisodecyl phthalates: Data from the 2005-2006 National Health and Nutrition Examination Survey. Environ. Health Perspect. 2011, 119, 50-55. [CrossRef]

141. Zota, A.R.; Calafat, A.M.; Woodruff, T.J. Temporal trends in phthalate exposures: Findings from the National Health and Nutrition Examination Survey, 2001-2010. Environ. Health Perspect. 2014, 122, 235-241. [CrossRef]

142. CDC. NHANES Fourth Annual Report. 2012. Available online: https://www.cdc.gov/exposurereport/pdf/ fourthreport.pdf (accessed on 5 April 2019).

143. Johns, L.E.; Cooper, G.S.; Galizia, A.; Meeker, J.D. Exposure assessment issues in epidemiology studies of phthalates. Environ. Int. 2015, 85, 27-39. [CrossRef]

144. Kim, J.H.; Park, H.; Lee, J.; Cho, G.; Choi, S.; Choi, G.; Kim, S.Y.; Eun, S.H.; Suh, E.; Kim, S.K.; et al. Association of diethylhexyl phthalate with obesity-related markers and body mass change from birth to 3 months of age. J. Epidemiol. Community Health 2016, 70, 466-472. [CrossRef]

145. Koch, H.M.; Drexler, H.; Angerer, J. Internal exposure of nursery-school children and their parents and teachers to di(2-ethylhexyl) phthalate (DEHP). Int. J. Hyg. Environ. Health 2004, 207, 15-22. [CrossRef] [PubMed]

146. Shea, K.M.; The AAP Committee on Environmental Health. Pediatric exposure and potential toxicity of phthalate plasticizers. Pediatrics 2003, 111, 1467-1474. [CrossRef] [PubMed]

147. Lin, S.; Ku, H.-Y.; Su, P.-H.; Chen, J.-W.; Huang, P.-C.; Angerer, J.; Wang, S.-L. Phthalate exposure in pregnant women and their children in central Taiwan. Chemosphere 2011, 82, 947-955. [CrossRef]

148. Calafat, A.M.; Weuve, J.; Ye, X.; Jia, L.T.; Hu, H.; Ringer, S.; Huttner, K.; Hauser, R. Exposure to bisphenol A and other phenols in neonatal intensive care unit premature infants. Environ. Health Perspect. 2009, 117, 639-644. [CrossRef]

149. Koch, H.M.; Preuss, R.; Angerer, J. Di(2-ethylhexyl)phthalate (DEHP): Human metabolism and internal exposure-An update and latest results. Int. J. Androl. 2006, 29, 155-165, discussion 181-185. [CrossRef] [PubMed]

150. Aylward, L.L.; Hays, S.M.; Gagne, M.; Krishnan, K. Derivation of Biomonitoring Equivalents for di-n-butyl phthalate (DBP), benzylbutyl phthalate (BzBP), and diethyl phthalate (DEP). Regul. Toxicol. Pharmacol. 2009, 55, 259-267. [CrossRef]

151. Hays, S.M.; Aylward, L.L.; Kirman, C.R.; Krishnan, K.; Nong, A. Biomonitoring Equivalents for di-isononyl phthalate (DINP). Regul. Toxicol. Pharmacol. 2011, 60, 181-188. [CrossRef] [PubMed]

152. Silva, M.J.; Barr, D.B.; Reidy, J.A.; Kato, K.; Malek, N.A.; Hodge, C.C.; Hurtz, D.; Calafat, A.M.; Needham, L.L.; Brock, J.W. Glucuronidation patterns of common urinary and serum monoester phthalate metabolites. Arch. Toxicol. 2003, 77, 561-567. [CrossRef]

153. Koch, H.M.; Bolt, H.M.; Preuss, R.; Angerer, J. New metabolites of di(2-ethylhexyl)phthalate (DEHP) in human urine and serum after single oral doses of deuterium-labelled DEHP. Arch. Toxicol. 2005, 79, 367-376. [CrossRef]

154. Mettang, T.; Alscher, D.M.; Pauli-Magnus, C.; Dunst, R.; Kuhlmann, U.; Rettenmeier, A.W. Phthalic acid is the main metabolite of the plasticizer di(2-ethylhexyl) phthalate in peritoneal dialysis patients. Adv. Perit. Dial. 1999, 15, 229-233. [PubMed]

155. Pollack, G.M.; Buchanan, J.F.; Slaughter, R.L.; Kohli, R.K.; Shen, D.D. Circulating concentrations of di(2-ethylhexyl) phthalate and its de-esterified phthalic acid products following plasticizer exposure in patients receiving hemodialysis. Toxicol. Appl. Pharmacol. 1985, 79, 257-267. [CrossRef] 
156. Choi, J.; Eom, J.; Kim, J.; Lee, S.; Kim, Y. Association between some endocrine-disrupting chemicals and childhood obesity in biological samples of young girls: A cross-sectional study. Environ. Toxicol. Pharmacol. 2014, 38, 51-57. [CrossRef] [PubMed]

157. Kardas, F.; Bayram, A.K.; Demirci, E.; Akin, L.; Ozmen, S.; Kendirci, M.; Canpolat, M.; Oztop, D.B.; Narin, F.; Gumus, H.; et al. Increased serum phthalates (MEHP, DEHP) and bisphenol A concentrations in children with autism spectrum disorder: The role of endocrine disruptors in autism etiopathogenesis. J. Child Neurol. 2016, 31, 629-635. [CrossRef]

158. Kim, S.; Lee, J.; Park, J.; Kim, H.J.; Cho, G.; Kim, G.H.; Eun, S.H.; Lee, J.J.; Choi, G.; Suh, E.; et al. Concentrations of phthalate metabolites in breast milk in Korea: Estimating exposure to phthalates and potential risks among breast-fed infants. Sci. Total Environ. 2015, 508, 13-19. [CrossRef] [PubMed]

159. Mortensen, G.K.; Main, K.M.; Andersson, A.-M.; Leffers, H.; Skakkebæk, N.E. Determination of phthalate monoesters in human milk, consumer milk, and infant formula by tandem mass spectrometry (LC-MS-MS). Anal. Bioanal. Chem. 2005, 382, 1084-1092. [CrossRef]

160. Kato, K.; Silva, M.J.; Needham, L.L.; Calafat, A.M. Quantifying phthalate metabolites in human meconium and semen using automated off-line solid-phase extraction coupled with on-line SPE and isotope-dilution high-performance liquid chromatography-tandem mass spectrometry. Anal. Chem. 2006, 78, 6651-6655. [CrossRef] [PubMed]

161. Herr, C.; zur Nieden, A.; Koch, H.M.; Schuppe, H.-C.; Fieber, C.; Angerer, J.; Eikmann, T.; Stilianakis, N.I. Urinary di(2-ethylhexyl)phthalate (DEHP)—Metabolites and male human markers of reproductive function. Int. J. Hyg. Environ. Health 2009, 212, 648-653. [CrossRef]

162. Buck Louis, G.M.; Smarr, M.M.; Sun, L.; Chen, Z.; Honda, M.; Wang, W.; Karthikraj, R.; Weck, J.; Kannan, K. Endocrine disrupting chemicals in seminal plasma and couple fecundity. Environ. Res. 2018, 163, 64-70. [CrossRef]

163. Smarr, M.M.; Kannan, K.; Sun, L.; Honda, M.; Wang, W.; Karthikraj, R.; Chen, Z.; Weck, J.; Buck Louis, G.M. Preconception seminal plasma concentrations of endocrine disrupting chemicals in relation to semen quality parameters among male partners planning for pregnancy. Environ. Res. 2018, 167, 78-86. [CrossRef]

164. Fabjan, E.; Hulzebos, E.; Mennes, W.; Piersma, A.H. A category approach for reproductive effects of phthalates. Crit. Rev. Toxicol. 2006, 36, 695-726. [CrossRef] [PubMed]

165. Lyche, J.L.; Gutleb, A.C.; Bergman, A.; Eriksen, G.S.; Murk, A.J.; Ropstad, E.; Saunders, M.; Skaare, J.U. Reproductive and developmental toxicity of phthalates. J. Toxicol. Environ. Health B Crit. Rev. 2009, 12, 225-249. [CrossRef]

166. Casals-Casas, C.; Desvergne, B. Endocrine disruptors: From endocrine to metabolic disruption. Annu. Rev. Physiol. 2011, 73, 135-162. [CrossRef] [PubMed]

167. Christiansen, S.; Boberg, J.; Axelstad, M.; Dalgaard, M.; Vinggaard, A.M.; Metzdorff, S.B.; Hass, U. Low-dose perinatal exposure to di(2-ethylhexyl) phthalate induces anti-androgenic effects in male rats. Reprod. Toxicol. 2010, 30, 313-321. [CrossRef] [PubMed]

168. Andrade, A.J.M.; Grande, S.W.; Talsness, C.E.; Grote, K.; Golombiewski, A.; Sterner-Kock, A.; Chahoud, I. A dose-response study following in utero and lactational exposure to di-(2-ethylhexyl) phthalate (DEHP): Effects on androgenic status, developmental landmarks and testicular histology in male offspring rats. Toxicology 2006, 225, 64-74. [CrossRef] [PubMed]

169. Culty, M.; Thuillier, R.; Li, W.P.; Wang, Y.; Martinez-Arguelles, D.B.; Benjamin, C.G.; Triantafilou, K.M.; Zirkin, B.R.; Papadopoulos, V. In utero exposure to di-(2-ethylhexyl) phthalate exerts both short-term and long-lasting suppressive effects on testosterone production in the rat. Biol. Reprod. 2008, 78, 1018-1028. [CrossRef] [PubMed]

170. Gray, L.E.; Barlow, N.J.; Howdeshell, K.L.; Ostby, J.S.; Furr, J.R.; Gray, C.L. Transgenerational Effects of Di (2-Ethylhexyl) Phthalate in the Male CRL:CD(SD) Rat: Added Value of Assessing Multiple Offspring per Litter. Toxicol. Sci. 2009, 110, 411-425. [CrossRef]

171. Jarfelt, K.; Dalgaard, M.; Hass, U.; Borch, J.; Jacobsen, H.; Ladefoged, O. Antiandrogenic effects in male rats perinatally exposed to a mixture of di(2-ethylhexyl) phthalate and di(2-ethylhexyl) adipate. Reprod. Toxicol. 2005, 19, 505-515. [CrossRef]

172. Vo, T.T.B.; Jung, E.M.; Dang, V.H.; Jung, K.; Baek, J.; Choi, K.C.; Jeung, E.B. Differential effects of flutamide and di-(2-ethylhexyl) phthalate on male reproductive organs in a rat model. J. Reprod. Dev. 2009, 55, 400-411. [CrossRef] 
173. Wilson, V.S.; Howdeshell, K.L.; Lambright, C.S.; Furr, J.; Gray, L.E. Differential expression of the phthalate syndrome in male Sprague-Dawley and Wistar rats after in utero DEHP exposure. Toxicol. Lett. 2007, 170, 177-184. [CrossRef]

174. Boberg, J.; Metzdorff, S.; Wortziger, R.; Axelstad, M.; Brokken, L.; Vinggaard, A.M.; Dalgaard, M.; Nellemann, C. Impact of diisobutyl phthalate and other PPAR agonists on steroidogenesis and plasma insulin and leptin levels in fetal rats. Toxicology 2008, 250, 75-81. [CrossRef] [PubMed]

175. Borch, J.; Axelstad, M.; Vinggaard, A.M.; Dalgaard, M. Diisobutyl phthalate has comparable anti-androgenic effects to di-n-butyl phthalate in fetal rat testis. Toxicol. Lett. 2006, 163, 183-190. [CrossRef] [PubMed]

176. Saillenfait, A.M.; Sabate, J.P.; Gallissot, F. Developmental toxic effects of diisobutyl phthalate, the methyl-branched analogue of di-n-butyl phthalate, administered by gavage to rats. Toxicol. Lett. 2006, 165, 39-46. [CrossRef]

177. Saillenfait, A.M.; Sabate, J.P.; Gallissot, F. Diisobutyl phthalate impairs the androgen-dependent reproductive development of the male rat. Reprod. Toxicol. 2008, 26, 107-115. [CrossRef] [PubMed]

178. Scott, H.M.; Hutchison, G.R.; Jobling, M.S.; McKinnell, C.; Drake, A.J.; Sharpe, R.M. Relationship between androgen action in the "Male Programming Window," fetal sertoli cell number, and adult testis size in the rat. Endocrinology 2008, 149, 5280-5287. [CrossRef] [PubMed]

179. Struve, M.F.; Gaido, K.W.; Hensley, J.B.; Lehmann, K.P.; Ross, S.M.; Sochaski, M.A.; Willson, G.A.; Dorman, D.C. Reproductive toxicity and pharmacokinetics of di-n-butyl phthalate (DBP) following dietary exposure of pregnant rats. Birth Defects Res. B Dev. Reprod. Toxicol. 2009, 86, 345-354. [CrossRef] [PubMed]

180. Kim, T.S.; Jung, K.K.; Kim, S.S.; Kang, I.H.; Baek, J.H.; Nam, H.S.; Hong, S.K.; Lee, B.M.; Hong, J.T.; Oh, K.W.; et al. Effects of in utero exposure to di(n-butyl) phthalate on development of male reproductive tracts in Sprague-Dawley rats. J. Toxicol. Environ. Health A Curr. Issues 2010, 73, 1544-1559. [CrossRef]

181. MacLeod, D.J.; Sharpe, R.M.; Welsh, M.; Fisken, M.; Scott, H.M.; Hutchison, G.R.; Drake, A.J.; van den Driesche, $\mathrm{S}$. Androgen action in the masculinization programming window and development of male reproductive organs. Int. J. Androl. 2010, 33, 279-286. [CrossRef]

182. Jiang, J.T.; Sun, W.L.; Jing, Y.F.; Liu, S.B.; Ma, Z.; Hong, Y.; Ma, L.; Qin, C.; Liu, Q.; Stratton, H.J.; et al. Prenatal exposure to di-n-butyl phthalate induces anorectal malformations in male rat offspring. Toxicology 2011, 290, 322-326. [CrossRef]

183. Howarth, J.A.; Price, S.C.; Dobrota, M.; Kentish, P.A.; Hinton, R.H. Effects on male rats of di-(2-ethylhexyl) phthalate and di-n-hexylphthalate administered alone or in combination. Toxicol. Lett. 2001, 121, 35-43. [CrossRef]

184. Zhai, W.H.; Huang, Z.G.; Chen, L.; Feng, C.; Li, B.; Li, T.S. Thyroid endocrine disruption in Zebrafish larvae after exposure to mono-(2-ethylhexyl) phthalate (MEHP). PLoS ONE 2014, 9, 92465-92471. [CrossRef]

185. O'Connor, J.C.; Frame, S.R.; Ladics, G.S. Evaluation of a 15-day screening assay using intact male rats for identifying antiandrogens. Toxicol. Sci. 2002, 69, 92-108. [CrossRef] [PubMed]

186. Larsen, S.T.; Hansen, J.S.; Hansen, E.W.; Clausen, P.A.; Nielsen, G.D. Airway inflammation and adjuvant effect after repeated airborne exposures to di-(2-ethylhexyl)phthalate and ovalbumin in BALB/c mice. Toxicology 2007, 235, 119-129. [CrossRef] [PubMed]

187. Dearman, R.J.; Beresford, L.; Bailey, L.; Caddick, H.T.; Betts, C.J.; Kimber, I. Di-(2-ethylhexyl) phthalate is without adjuvant effect in mice on ovalbumin. Toxicology 2008, 244, 231-241. [CrossRef] [PubMed]

188. Li, Y.F.; Zhuang, M.Z.; Li, T.; Shi, N. Neurobehavioral toxicity study of dibutyl phthalate on rats following in utero and lactational exposure. J. Appl. Toxicol. 2009, 29, 603-611. [CrossRef]

189. Li, X.J.; Jiang, L.; Chen, L.; Chen, H.S.; Li, X. Neurotoxicity of dibutyl phthalate in brain development following perinatal exposure: A study in rats. Environ. Toxicol. Pharmacol. 2013, 36, 392-402. [CrossRef]

190. Tanaka, T. Reproductive and neurobehavioural toxicity study of bis(2-ethylhexyl) phthalate (DEHP) administered to mice in the diet. Food Chem. Toxicol. 2002, 40, 1499-1506. [CrossRef]

191. Hoshi, H.; Ohtsuka, T. Adult rats exposed to low-doses of di-n-butyl phthalate during gestation exhibit decreased grooming behavior. Bull. Environ. Contam. Toxicol. 2009, 83, 62-66. [CrossRef]

192. Sun, Q.; Cornelis, M.C.; Townsend, M.K.; Tobias, D.K.; Heather Eliassen, A.; Franke, A.A.; Hauser, R.; Hu, F.B. Association of urinary concentrations of bisphenol A and phthalate metabolites with risk of type 2 diabetes: A prospective investigation in the nurses' health study (NHS) and NHSII cohorts. Environ. Health Perspect. 2014, 122, 616-623. [CrossRef] 
193. Stahlhut Richard, W.; van Wijngaarden, E.; Dye Timothy, D.; Cook, S.; Swan Shanna, H. Concentrations of urinary phthalate metabolites are associated with increased waist circumference and insulin resistance in adult U.S. males. Environ. Health Perspect. 2007, 115, 876-882. [CrossRef]

194. Trasande, L.; Sathyanarayana, S.; Spanier, A.J.; Trachtman, H.; Attina, T.M.; Urbina, E.M. Urinary phthalates are associated with higher blood pressure in childhood. J. Pediatr. 2013, 163, 747-753. [CrossRef]

195. Wang, H.; Zhou, Y.; Tang, C.; He, Y.; Wu, J.; Chen, Y.; Jiang, Q. Urinary phthalate metabolites are associated with body mass index and waist circumference in Chinese school children. PLoS ONE 2013, 8, 56800-56809. [CrossRef] [PubMed]

196. Buser, M.C.; Murray, H.E.; Scinicariello, F. Age and sex differences in childhood and adulthood obesity association with phthalates: Analyses of NHANES 2007-2010. Int. J. Hyg. Environ. Health 2014, 217, 687-694. [CrossRef] [PubMed]

197. Zhang, Y.; Meng, X.; Chen, L.; Li, D.; Zhao, L.; Zhao, Y.; Li, L.; Shi, H. Age and sex-specific relationships between phthalate exposures and obesity in Chinese children at puberty. PLoS ONE 2014, 9, e104852. [CrossRef] [PubMed]

198. Hatch, E.; Nelson, J.; Qureshi, M. Association of urinary phthalate metabolite concentrations with body mass index and waist circumference: A crosssectional study of NHANES data 1999-2002. Environ. Health 2008, 15, 1-15. [CrossRef] [PubMed]

199. Dirtu, A.C.; Geens, T.; Dirinck, E.; Malarvannan, G.; Neels, H.; Van Gaal, L.; Jorens, P.G.; Covaci, A. Phthalate metabolites in obese individuals undergoing weight loss: Urinary levels and estimation of the phthalates daily intake. Environ. Int. 2013, 59, 344-353. [CrossRef] [PubMed]

200. Braun, J.M.; Sathyanarayana, S.; Hauser, R. Phthalate exposure and children's health. Curr. Opin. Pediatr. 2013, 25, 247-254. [CrossRef] [PubMed]

201. Hoppin, J.A.; Jaramillo, R.; London, S.J.; Bertelsen, R.J.; Salo, P.M.; Sandler, D.P.; Zeldin, D.C. Phthalate exposure and allergy in the U.S. population: Results from NHANES 2005-2006. Environ. Health Perspect. 2013, 121, 1129-1134. [CrossRef] [PubMed]

202. Ait Bamai, Y.; Shibata, E.; Saito, I.; Araki, A.; Kanazawa, A.; Morimoto, K.; Nakayama, K.; Tanaka, M.; Takigawa, T.; Yoshimura, T.; et al. Exposure to house dust phthalates in relation to asthma and allergies in both children and adults. Sci. Total Environ. 2014, 485-486, 153-163. [CrossRef] [PubMed]

203. Wang, I.J.; Karmaus, W.J.; Chen, S.L.; Holloway, J.W.; Ewart, S. Effects ofphthalate exposure on asthma may be mediated through alterations in DNAmethylation. Clin. Epigenet. 2015, 7, 27-36. [CrossRef]

204. Gascon, M.; Casas, M.; Morales, E.; Valvi, D.; Ballesteros-Gómez, A.; Luque, N.; Rubio, S.; Monfort, N.; Ventura, R.; Martínez, D.; et al. Prenatal exposure to bisphenol A and phthalates and childhood respiratory tract infections and allergy. J. Allergy Clin. Immunol. 2015, 135, 370-378. [CrossRef] [PubMed]

205. Frederiksen, H.; Sørensen, K.; Mouritsen, A.; Aksglaede, L.; Hagen, C.P.; Petersen, J.H.; Skakkebaek, N.E.; Andersson, A.M.; Juul, A. High urinary phthalate concentration associated with delayed pubarche in girls. Int. J. Androl. 2012, 35, 216-226. [CrossRef]

206. Upson, K.; Sathyanarayana, S.; De Roos, A.J.; Thompson, M.L.; Scholes, D.; Dills, R.; Holt, V.L. Phthalates and risk of endometriosis. Environ. Res. 2013, 126, 91-97. [CrossRef]

207. Durmaz, E.; Özmert, E.N.; Erkekoğlu, P.; Giray, B.; Derman, O.; Hıncal, F.; Yurdakök, K. Plasma phthalate levels in pubertal gynecomastia. Pediatrics 2010, 125, 122-129. [CrossRef] [PubMed]

208. Radke, E.G.; Braun, J.M.; Meeker, J.D.; Cooper, G.S. Phthalate exposure and male reproductive outcomes: A systematic review of human epidemiological evidence. Environ. Int. 2018, 121, 764-793. [CrossRef] [PubMed]

(C) 2019 by the authors. Licensee MDPI, Basel, Switzerland. This article is an open access article distributed under the terms and conditions of the Creative Commons Attribution (CC BY) license (http://creativecommons.org/licenses/by/4.0/). 